\title{
Molecular Mechanism Underlying Anti-Inflammatory and Anti-Allergic Activities of Phytochemicals: An Update
}

\author{
Yuva Bellik ${ }^{1,2}$, Laïd Boukraâ ${ }^{1,3, *}$, Hasan A. Alzahrani ${ }^{3,4}$, Balkees A. Bakhotmah ${ }^{3,5}$, \\ Fatiha Abdellah ${ }^{1}$, Si M. Hammoudi ${ }^{1}$ and Mokrane Iguer-Ouada ${ }^{2}$
}

1 Laboratory of Research on Local Animal Products, Ibn-Khaldoun University of Tiaret, Tiaret 14000, Algeria; E-Mails: bellik_youva@yahoo.fr (Y.B.); fatiha.abdellah@yahoo.fr (F.A.); mouh_hammoudi@yahoo.com (S.M.H.)

2 Faculty of Nature and Life Sciences, Abderrahmane Mira University, Béjaia 06000, Algeria; E-Mail: imokrane@gmail.com

3 Mohammad Hussein Al Amoudi Chair for Diabetic Foot Research, King Abdulaziz University, Jeddah 21589, Saudi Arabia; E-Mails: haaz59@yahoo.com (H.A.A.); hbaab1961@yahoo.com (B.A.B.)

4 Department of Surgery, Faculty of Medicine, King Abdulaziz University, Jeddah 21589, Saudi Arabia

5 Department of Nutrition Food Sciences, Arts and Design College, King Abdulaziz University, Jeddah 21589, Saudi Arabia

* Author to whom correspondence should be addressed; E-Mail: laid_bouk@hotmail.com; Tel./Fax: +213-795-306-930.

Received: 13 September 2012; in revised form: 6 December 2012 / Accepted: 14 December 2012 / Published: 27 December 2012

\begin{abstract}
The resort worldwide to edible medicinal plants for medical care has increased significantly during the last few years. Currently, there is a renewed interest in the search for new phytochemicals that could be developed as useful anti-inflammatory and anti-allergic agents to reduce the risk of many diseases. The activation of nuclear transcription factor-kappa $\mathrm{B}(\mathrm{NF}-\mathrm{\kappa} \mathrm{B})$ has now been linked to a variety of inflammatory diseases, while data from numerous studies underline the importance of phytochemicals in inhibiting the pathway that activates this transcription factor. Moreover, the incidence of type I allergic disorders has been increasing worldwide, particularly, the hypersensitivity to food. Thus, a good number of plant products with anti-inflammatory and anti-allergic activity have been documented, but very few of these compounds have reached clinical use and there is scant scientific evidence that could explain their mode of action. Therefore, this paper intends to review the most salient recent reports on the anti-inflammatory and anti-allergic properties of phytochemicals and the molecular mechanisms underlying these properties.
\end{abstract}


Keywords: phytochemicals; anti-inflammatory; anti-allergic; molecular mechanisms

\section{Introduction}

Plants have been the basis of many traditional medicine systems throughout the World for thousands of years and still remain as the main new source of structurally important chemical substances that lead to the development of innovative drugs $[1,2]$. The use of medicinal plants for the treatment of many diseases is associated with folk medicine from different parts of the World $[3,4]$. Nowadays, the search for new anti-inflammatory and anti-allergic agents from the huge array of medicinal plant resources is intensifying [5]. In fact, a variety of bioactive components have been shown to modulate inflammatory responses [6]. The inflammatory response is a critical protective reaction to irritation, injury, or infection, characterised by redness, heat, swelling, loss of function and pain [7]. Redness and heat result from an increase in blood flow, swelling is associated with increased vascular permeability, and pain is the consequence of activation and sensitisation of primary afferent nerve fibres [8].

The understanding of the cellular and molecular mechanisms involved in the inflammatory process has increased considerably in recent decades and this has permitted the discovery of many promising targets for the development of new drugs to treat chronic inflammatory diseases [8]. A great number of inflammatory mediators including kinins, platelet-activating factor (PAF), prostaglandins, leukotrienes, amines, purines, cytokines, chemokines and adhesion molecules, has been found to act on specific targets, leading to the local release of other mediators from leukocytes and the further attraction of leukocytes, such as neutrophils, to the site of inflammation [6].

The constant advent of new findings from immunohistochemical, biochemical, molecular and functional animal models, together with clinical trials, has greatly increased the interest in the study of the mechanisms that underlie the inflammatory process [8]. Recently, roles have been identified for several inflammatory cells and for a large number of inflammatory mediators in important pathologies not previously known to be linked to inflammation, such as Alzheimer's disease and cardiovascular disorders including atherosclerosis, as well as cancer, reviewed in Akiyama et al. [9] and Libby et al. [10].

Natural products have long been, over the years, contributed to the development of modern therapeutic drugs [11]. Evidence exists that drugs derived from natural products can modulate various inflammatory mediators (arachidonic acid metabolites, peptides, cytokines, excitatory amino acids, etc.), the production and/or action of second messengers (cGMP, cAMP, protein kinases, and calcium), the expression of transcription factors such as AP-1, NF- $\kappa \mathrm{B}$, and proto-oncogenes (c-jun, $c-f o s$, and $c-m y c)$, and the expression of key pro-inflammatory molecules such as inducible NO synthase (iNOS), cyclooxygenase (COX-2), cytokines (IL-1 $\beta, \mathrm{TNF}-\alpha$ ), neuropeptides and proteases [6-8].

In parallel, the allergic process has an important inflammatory component in which mast cell activation and degranulation are the first phenomena observed. During this process, mast cells release several inflammatory mediators including histamine (5-HT), platelet aggregating factor (PAF), leukotrienes, and a variety of cytokines $[12,13]$. Hypersensitivity type I, an allergic reaction, is an $\operatorname{IgE}$ mediated immune response, resulting in histamine secretion from mast cells and blood basophils. The 
early phase reaction of allergy occurs within minutes after allergen exposure, whereas the late phase reaction occurs hours later and involves in cytokines secretion such as TNF- $\alpha$ and IL-4 [14].

The discovery of drugs that can be used for the treatment of inflammatory and allergic diseases is important in human health. Drug discovery from plants involves a multidisciplinary approach combining botanical, ethnobotanical, phytochemical and biological techniques [2]. Several natural product drugs of plant origin are in clinical use and some are undergoing Phase II and Phase III clinical trials [2-5]. This review highlights the current patents about the potential benefits and effectiveness of phytochemicals that have shown experimental or clinical anti-inflammatory or anti-allergic activities, the possible mechanism of action and their therapeutic value.

\section{Major Classes of Phytochemicals}

Plants are rich in a wide variety of secondary metabolites, the great majority of which do not appear to participate directly in growth and development [15]. Based on their biosynthetic origins, phytochemicals can be classified as carotenoids, phenolics, alkaloids, nitrogen-containing compounds, and organosulfur compounds. Interestingly, an important classification has been depicted by Liu [16] gathering nearly most of dietary phytochemical classes and the structures of their main chemically relevant components (Figure 1).

Figure 1. Classification of dietary phytochemicals [16].

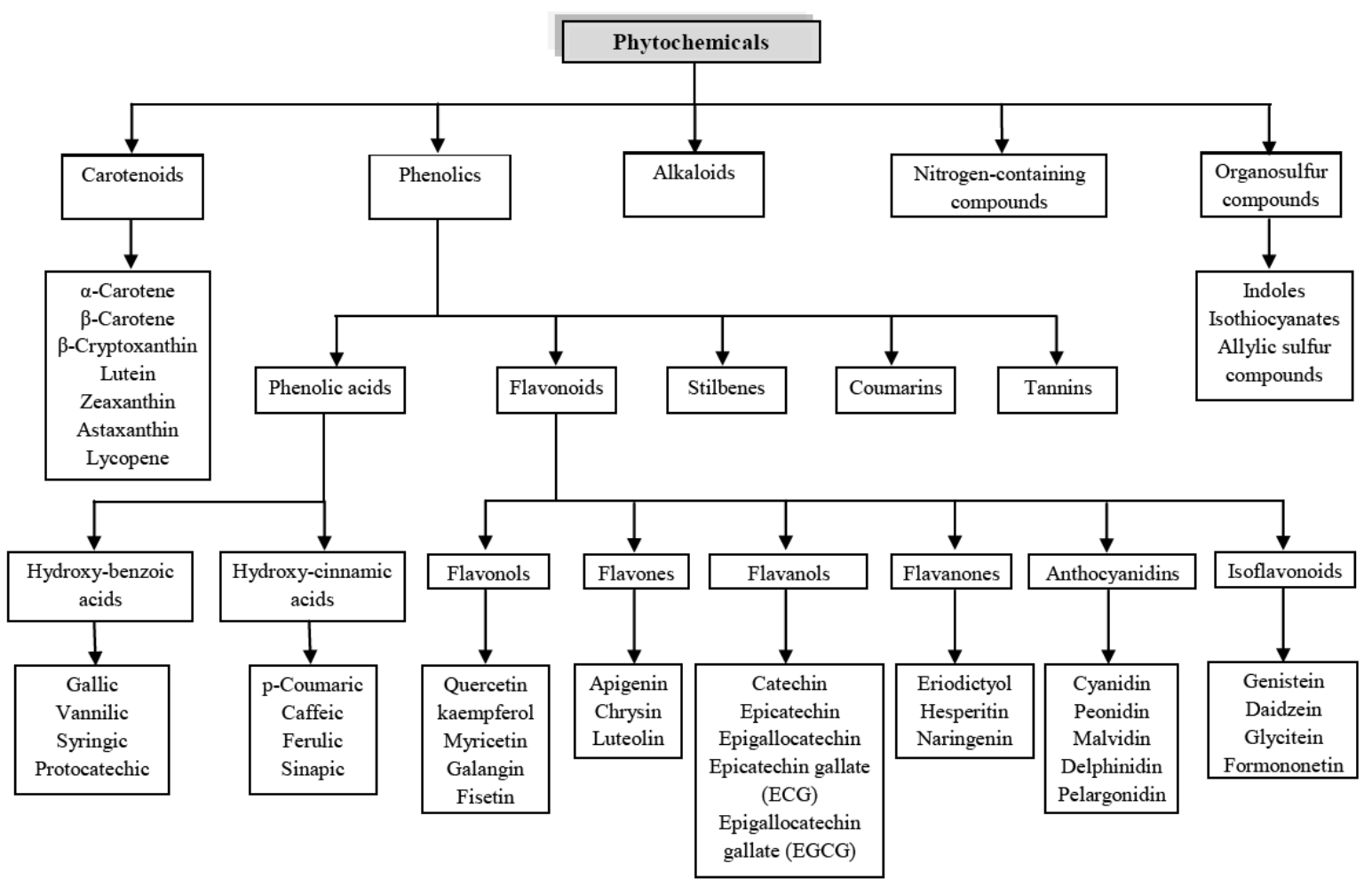

Phytochemicals, although noted for the complexity of their chemical structures and biosynthetic pathways, they have been widely perceived as biologically insignificant and have historically received little attention from most plant biologists. Organic chemists, however, have long been interested in these novel phytochemicals and have investigated their chemical properties extensively since the 1850s [15]. At present numerous studies have established that the phytochemical content of plants contributes to their protective effects against acute, chronic, and degenerative diseases [17-19]. 


\section{Molecular Mechanism Underlying Phytochemicals}

\subsection{Inflammation}

Wide ranges of phytoconstituents were responsible for anti-inflammatory activity including phenolics, alkaloids, and terpenoids [19]. However, efforts have focused on a class of compounds to elucidate the mechanisms of action of herbs, characterize and establish their potential utility as therapeutic agents in the treatment of inflammatory diseases.

Several mechanisms of action have been proposed to explain the anti-inflammatory actions of phytoconstituents, it consist broadly in: (1) Antioxidative and radical scavenging activities; (2) Modulation of cellular activities of inflammation-related cells (mast cells, macrophages, lymphocytes, and neutrophils); (3) Modulation of proinflammatory enzyme activities such as phospholipase $\mathrm{A}_{2}\left(\mathrm{PLA}_{2}\right)$, cyclooxygenase $(\mathrm{COX})$, and lipoxygenase (LOX) and the nitric oxide (NO) producing enzyme, nitric oxide synthase (NOS); (4) Modulation of the production of other proinflammatory molecules; (5) Modulation of proinflammatory gene expression.

The Tables 1 and 2 summarize the most studied and well-known phytochemicals including polyphenols (Figure 2), alkaloids (Figure 3), and terpenes (Figure 4) compounds with anti-inflammatory activities and their cellular and molecular mechanism. It should be noted that several other reports demonstrating the similar results are not represented here.

Figure 2. Chemical structures of polyphenols. Modified from Vauzour [20].

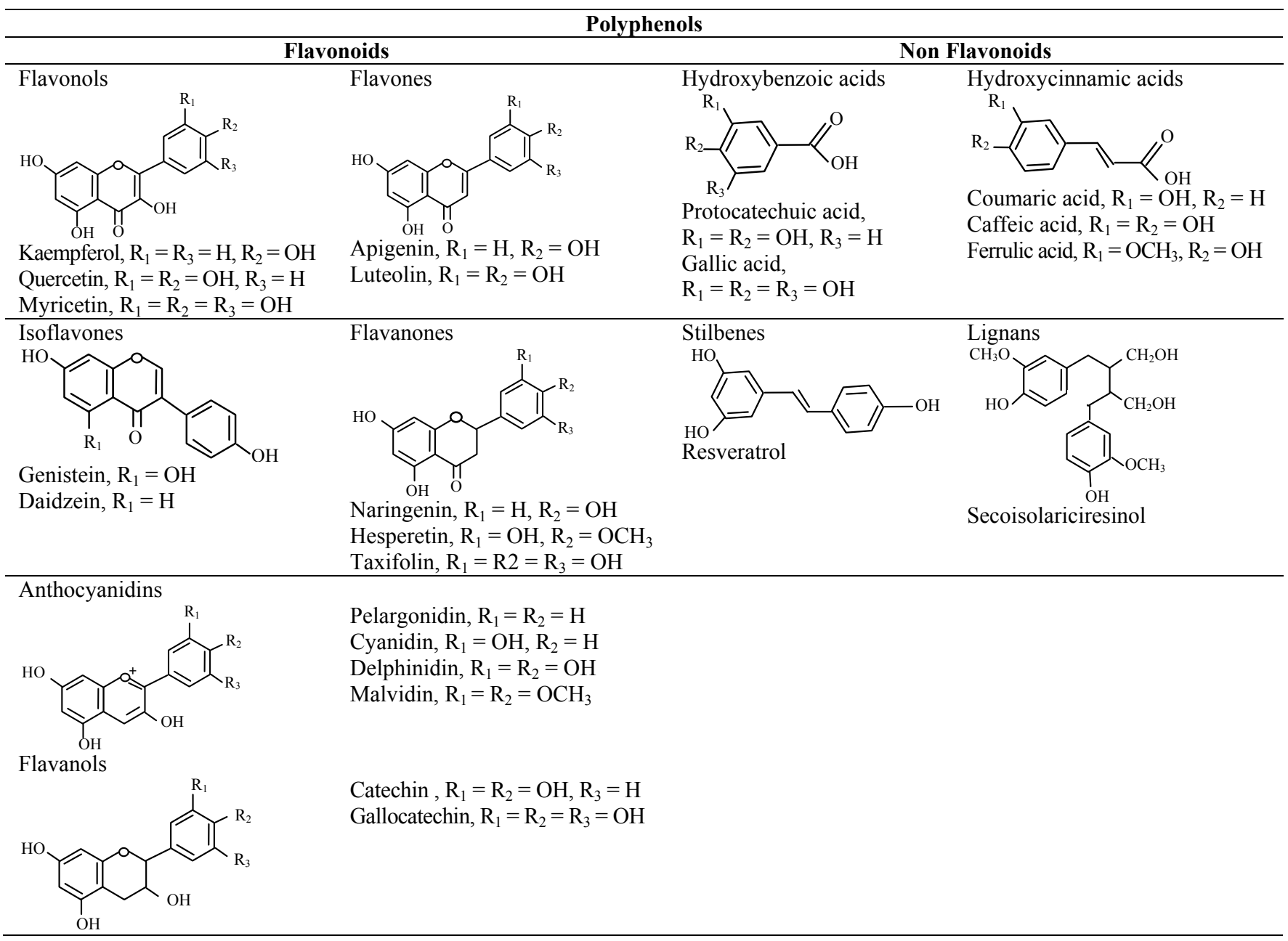


Table 1. Anti-inflammatory activities of phytochemicals.

\begin{tabular}{|c|c|c|c|c|}
\hline Target pathway & Effects & Compounds & Mechanism of action & References \\
\hline \multirow{10}{*}{$\begin{array}{l}\text { Antioxidative and } \\
\text { radical scavenging } \\
\text { activities }\end{array}$} & $\begin{array}{l}\text { Promoting antioxidant } \\
\text { enzymes activity }\end{array}$ & Quercetin, resveratrol, curcumin, hydroxytyrosol, catechin, luteolin & $\begin{array}{l}\text { Increasing the activity of superoxide dismutase } \\
\text { (SOD), catalase (CAT), glutathione peroxidase } \\
\text { (GPx), glutathione reductase (GR), glutathione } \\
S \text {-transferase (GST), } \gamma \text {-glutamylcysteine synthetase } \\
(\gamma \text {-GCS) NADPH:quinone oxidoreductase-1 } \\
\text { (NQO1) and heat shock proteins } 70 \text { (HSP70) } \\
\text { expression }\end{array}$ & {$[21-30]$} \\
\hline & \multirow{5}{*}{$\begin{array}{l}\text { Inhibiting pro-oxidant } \\
\text { enzymes activity }\end{array}$} & Epigallocatechin, ECG, EGCG & Inhibiting lipoxygenase and cyclooxygenase & [31] \\
\hline & & Typheramide, alfrutamide, (-)-epicatechin, procyanidin & $\begin{array}{l}\text { Inhibiting the activities of 5- lipoxygenase, } 12 \text { - } \\
\text { lipoxygenase and 15-lipoxygenase }\end{array}$ & {$[32,33]$} \\
\hline & & Curcumin, resveratrol, lupeol & $\begin{array}{l}\text { Decreasing the activity of iNOS and } \\
\text { myeloperoxidase (MPO) level }\end{array}$ & {$[24,30,34]$} \\
\hline & & Ellagic acid gallic, acid corilagin, luteolin & Inhibiting tyrosinase and xanthine oxidase & {$[35,36]$} \\
\hline & & Resveratrol & $\begin{array}{l}\text { Inhibiting } O \text {-acetyltransferase and } \\
\text { sulfotransferase activities }\end{array}$ & {$[37]$} \\
\hline & \multirow{3}{*}{$\begin{array}{l}\text { Prevent free radical } \\
\text { attacks }\end{array}$} & Epicatechin, rutin, mannitol & Scavenging hydroxyl radical $\left(\mathrm{OH}^{\circ}\right)$ & {$[38]$} \\
\hline & & Ellagic acid gallic, acid corilagin, luteolin, $\beta$-carotene, tetrandrine & Scavenging superoxide radical $\left(\mathrm{O}_{2}\right)^{\circ}$ & {$[35,36,39,40]$} \\
\hline & & Quercetin, curcumin, lycopene & Decreasing MDA and lipoperoxidation & {$[22,30,41]$} \\
\hline & $\begin{array}{l}\text { Enhancing endogenous } \\
\text { antioxidant molecules }\end{array}$ & Quercetin, resveratrol, catechin, proanthocyanidin B4, $\beta$-carotene & Elevating cellular GSH content & {$[21,24,26,42]$} \\
\hline \multirow{2}{*}{$\begin{array}{l}\text { Modulation of } \\
\text { cellular activities } \\
\text { of inflammation- } \\
\text { related cells }\end{array}$} & \multirow{2}{*}{$\begin{array}{l}\text { Inhibition of enzymes } \\
\text { involved in signaling } \\
\text { transduction and cell } \\
\text { activation processes } \\
\text { (T cell, B lymphocyte) or } \\
\text { cytokine production }\end{array}$} & Genistein & $\begin{array}{l}\text { Inhibition of tyrosine protein kinase inducing } \\
\text { anti-proliferative effects on T cell, reducing } \\
\text { IL-2 secretion and IL-2R expression }\end{array}$ & {$[43,44]$} \\
\hline & & Quercetin, kaempferol, apigenin, chrysin, luteolin & $\begin{array}{l}\text { Inhibition of tyrosine protein kinase inducing } \\
\text { anti-proliferative effects on M-CSF-activated } \\
\text { macrophages }\end{array}$ & [45] \\
\hline
\end{tabular}


Table 1. Cont.

\begin{tabular}{|c|c|c|c|c|}
\hline Target pathway & Effects & Compounds & Mechanism of action & References \\
\hline \multirow{3}{*}{$\begin{array}{l}\text { Modulation of } \\
\text { cellular activities } \\
\text { of inflammation- } \\
\text { related cells }\end{array}$} & \multirow{3}{*}{$\begin{array}{l}\text { Inhibition of } \\
\text { arachidonic acid release } \\
\text { from membranes } \\
\text { (degranulation) }\end{array}$} & \multirow[t]{2}{*}{ Quercetin } & $\begin{array}{l}\text { Inhibiting lysosomal enzyme release from } \\
\text { stimulated neutrophil (elastase, } \\
\beta \text {-glucuronidase) }\end{array}$ & [46-48] \\
\hline & & & $\begin{array}{l}\text { Impairing lysosomal enzyme release from } \\
\text { polymorphonuclear leukocytes }\end{array}$ & {$[47,49,50]$} \\
\hline & & Rutin & $\begin{array}{l}\text { Reducing the polymorphonuclear neutrophils } \\
\text { chemotaxis to FMLP }\end{array}$ & {$[51]$} \\
\hline \multirow{6}{*}{$\begin{array}{l}\text { Modulation of } \\
\text { arachidonic acid } \\
\text { (AA) related } \\
\text { enzymes }\end{array}$} & $\begin{array}{l}\text { Inhibition of } \\
\text { arachidonic acid } \\
\text { metabolism }\end{array}$ & $\begin{array}{l}\text { Quercetin, kaempferol, myricetin, hesperetin, naringenin, quercetagetin, } \\
\text { kaempferol-3-galactoside, scutellarein, ochnaflavone, amentoflavone, } \\
\text { ginkgetin, morelloflavone, bilobetin, triptolide, papyriflavonol A }\end{array}$ & Inhibition of PLA2 activity & {$[50-59]$} \\
\hline & \multirow{5}{*}{$\begin{array}{l}\text { Inhibition of } \\
\text { proinflammatory } \\
\text { enzymes (COX, LOX } \\
\text { and NOS) from different } \\
\text { sources }\end{array}$} & $\begin{array}{l}\text { Luteolin, 3',4'-dihydroxyflavone, galangin, morin, apigenein, chrysin, } \\
\text { quercetin, myricetin, morusin, kuwanon } \mathrm{C} \text {, sanggenon } \mathrm{D} \text {, broussoaurone } \\
\text { A, cycloheterophyllin, broussochalcone A broussoflavonol F, catechin, } \\
\text { EGCG, resveratrol, xanthomicrol, cirsiliol, hypolaetin, diosmetin, } \\
\text { tectorigenin, kuraridin, kurarinone, sophoraflavanone G, morusin, } \\
\text { sanggenon B, kazinol B, rutaecarpine, 1,2-di-O- } \alpha \text {-linolenoyl-3-O- } \beta \text { - } \\
\text { galactopyranosyl-sn-glycerol (dlGG), curcumin, 4'-Me-gallocatechin, } \\
\text { lonchocarpol A, tomentosanol D, catechins, catechins gallate }\end{array}$ & Inhibited COX activity & {$[6,58,60-74]$} \\
\hline & & $\begin{array}{l}\text { Sophoraflavanone G, kenusanone A, kuraridin, papyriflavonol A, } \\
\text { sanggenon B, sanggenon D, boswellic acid, diphyllin acetylapioside }\end{array}$ & Inhibited 5-LOX activity & {$[69,75-77]$} \\
\hline & & $\begin{array}{l}\text { Quercetin, kaempferol, fisetin, quercetagetin-7-O-glucoside, hibifolin, } \\
\text { hypolaetin, sideritoflavone, 5,6,7-trihydroxyflavone (baicalein) }\end{array}$ & Inhibited 12-LOX activity & {$[6,78]$} \\
\hline & & Kaempferol, quercetin, myricetin, morin, cirsiliol, artonins & Inhibited 5-LOX and 12-LOX activity & [79-82] \\
\hline & & Quercetin & Inhibited eNOS activity & [83] \\
\hline
\end{tabular}


Table 1. Cont.

\begin{tabular}{|c|c|c|c|c|}
\hline Target pathway & Effects & Compounds & Mechanism of action & References \\
\hline \multirow{9}{*}{$\begin{array}{l}\text { Modulation of the } \\
\text { production of } \\
\text { other } \\
\text { proinflammatory } \\
\text { molecules }\end{array}$} & \multirow{9}{*}{$\begin{array}{l}\text { Inhibition of } \\
\text { proinflammatory } \\
\text { cytokines from different } \\
\text { sources }\end{array}$} & Formononetin & Inhibited iNOS activity & [84] \\
\hline & & $\begin{array}{l}\text { Genistein, apigenin, quercetin, morin, wogonin, soyisoflavones, } \\
\text { daidzein, glycitein, dlGG, paeonol }\end{array}$ & Inhibited NO production & {$[71,85-89]$} \\
\hline & & $\begin{array}{l}\text { Genistein, quercetin, wogonin, baicalein, luteolin, nobiletin, paeonol, } \\
\text { chlorogenic acid, hematein, aucubin, catalposide, tetrandrine, } \\
\text { fangchinoline, colchicines, piperlactam S }\end{array}$ & Inhibited cytokine production : IL-1 $\beta$, IL- 6 , TNF- $\alpha$ & [89-101] \\
\hline & & $\begin{array}{l}\text { Curcumin, amoradicin, genistein, silybin, quercetin, wogonin, rutin, } \\
\text { luteolin, eriodictyol, hesperitin, EGCG, geraniin, corilagin, pinoresinol, } \\
\text { woorenoside, lariciresinol glycoside, terpinen-4-ol, physalin B, } \\
\text { triptolide, lupeol, [6]-shogaol, vitamin D, cepharanthine, fangchinoline, } \\
\text { adenosine }\end{array}$ & Inhibited TNF- $\alpha$ production & $\begin{array}{l}{[34,98,} \\
102-123]\end{array}$ \\
\hline & & Apigenin, wogonin, bacalein & Inhibited IL- 6 and IL-8 production & {$[124,125]$} \\
\hline & & Genistein, ilicic acid, inuviscolide acid, tryptanthrin & Inhibited $\mathrm{LTB}_{4}$ production & {$[126-128]$} \\
\hline & & Saikosaponins, masticaienonic acid, masticadienolic acid, morolic acid & Reducing $\mathrm{LTC}_{4}$ production & [128-131] \\
\hline & & $\begin{array}{l}\text { Chrysin, flavone, galangin, kaempferol, quercetin, salidroside, syringin, } \\
\text { phillyrin, coniferin, tryptanthrin }\end{array}$ & Inhibited $\mathrm{TXB}_{2}$ production & {$[79,128,132]$} \\
\hline & & $\begin{array}{l}\text { Lupeol, paeonol, quercetin, salidroside, syringin, phillyrin, tectorigenin, } \\
\text { tectoridin, platycodin D, } \beta \text {-turmerone, ar-turmerone, rutaecarpine }\end{array}$ & Inhibited PGE2 production & $\begin{array}{l}{[34,89,105} \\
132-136]\end{array}$ \\
\hline
\end{tabular}


Table 1. Cont.

\begin{tabular}{|c|c|c|c|c|}
\hline Target pathway & Effects & Compounds & Mechanism of action & References \\
\hline \multirow{5}{*}{$\begin{array}{l}\text { Modulation of } \\
\text { proinflammatory } \\
\text { gene expression }\end{array}$} & \multirow{5}{*}{$\begin{array}{l}\text { Inhibition of the } \\
\text { expression of various } \\
\text { inflammation-related } \\
\text { proteins/enzymes, by } \\
\text { suppressing activation of } \\
\text { transcription factors such } \\
\text { as } N F-\kappa B \text { and } A P-1\end{array}$} & Baicalein, oroxylin A, baicalin, skullcapflavone II & Inhibited eotaxin production & [137] \\
\hline & & $\begin{array}{l}\text { Rutin, bilobetin, ginkgetin, isoginkgetin, ochnaflavone, morusin, } \\
\text { kuwanon } \mathrm{C} \text {, kazinol } \mathrm{B} \text {, sanggenon } \mathrm{B} \text { and } \mathrm{D} \text {, echinoisoflavanone, } \\
\text { wogonin, apigenin, kaempferol, genistein, chrysin, luteolin, quercetin, } \\
\text { myricetin, flavone, tectorigenin, nobiletin, oroxylin } \mathrm{A} \text {, galangin, } \\
\text { EGCG, isoliquiritigenin, silymarin, curcumin, flavones, daidzein, } \\
\text { glycitein, isorhamnetin, naringenin, pelargonidin, soyisoflavones, } \\
\text { wogonin, resveratrol, triptolide, lupeol, butyrate, zeaxanthin, } \beta \text {-carotene }\end{array}$ & Inhibited iNOS expression & $\begin{array}{l}{[56,84,87,} \\
138-157]\end{array}$ \\
\hline & & $\begin{array}{l}\text { Bilobetin, ginkgetin, paeonol, tectorigenin, tectoridin, platycodin D, } \\
\text { apigenin, genistein, kaempferol, quercetin, myricetin, nobiletin, } \\
\text { rhamnetin, eriodictyol, luteolin, fisetin, phloretin, wogonin, galangin, } \\
\text { oroxylin A, lupeol, isoliquiritigenin, amentoflavone, butyrate, ursolic } \\
\text { acid, iridoid, pendunculariside, agnuside, ferulic acid, [6]-Gingerol, } \\
\text { resveratrol, EGCG }\end{array}$ & Inhibited COX-2 expression & $\begin{array}{l}{[56,89,133} \\
134,140-143 \\
147,154 \\
158-172]\end{array}$ \\
\hline & & $\begin{array}{l}\text { Lycopene, dlGG, wogonin, genistein, apigenin, kaempferol, myricetin, } \\
\text { oroxylin, silymarin, } \beta \text {-carotene, resveratrol, quercetin, avicins, } \\
\text { parthenolide, chlorogenic acid, triptolide, capsaicin, butyrate, luteolin, } \\
\text { curcumin }\end{array}$ & Inhibition of NF- $\kappa$ B activation & $\begin{array}{l}{[41,71,87,90,140,} \\
142,145,148,157, \\
171,173-181]\end{array}$ \\
\hline & & Hematein, casearinols A and B, casearinones A and B, colchicine & $\begin{array}{l}\text { Inhibited the expression of ICAM- } 1 \text { and } \\
\text { VCAM- } 1 \text { on the surface of different cells }\end{array}$ & {$[95,182,183]$} \\
\hline
\end{tabular}


Figure 3. Chemical structures of alkaloids. Adapted from Gautam and Jachak [7].<smiles>O=C1C2C=CC=CN2c2nc3ccccc3c(=O)n21</smiles>

Tryptanhrin

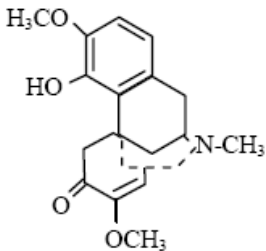

Sinomenine<smiles></smiles>

Piperlactam S<smiles></smiles>

Rutaecarpine

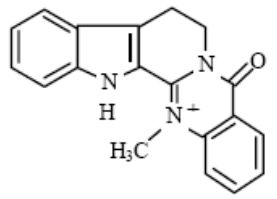

Dehydroevodiamine<smiles></smiles>

Evodiamine<smiles>[R]c1c2[n+](cc3c(OC)c(OC)ccc13)CCc1cc3c(cc1-2)OCO3</smiles>

Berberine, $\mathrm{R}=\mathrm{H}$

13-methylberberine, $\mathrm{R}=\mathrm{CH}_{3}$ 13-ethylberberine, $\mathrm{R}=\mathrm{C}_{2} \mathrm{H}_{5}$
Fangchinoline, $\mathrm{R}=\mathrm{H}$

Tetrandrine, $\mathrm{R}=\mathrm{CH}_{3}$<smiles>[R]c1cccc2c1[nH]c1c(C=C)ncc(OC)c12</smiles>

$\beta$ - carboline

Figure 4. Chemical structures of terpenoids. Adapted from Gautam and Jachak [7].

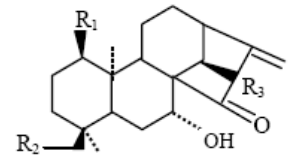

Akurane diterpenoids $1, \mathrm{R}_{1}=\mathrm{R}_{2}=\mathrm{H}, \mathrm{R}_{3}=\mathrm{OH}$

Akurane diterpenoids 2, $\mathrm{R}_{1}=\mathrm{H}, \mathrm{R}_{2}=\mathrm{OAc}, \mathrm{R}_{3}=\mathrm{H}$ Akurane diterpenoids $3, \mathrm{R}_{1}=\mathrm{OAc}, \mathrm{R}_{2}=\mathrm{H}, \mathrm{R}_{3}=\mathrm{OH}$ Akurane diterpenoids $4, \mathrm{R}_{1}=\mathrm{H}, \mathrm{R}_{2}=\mathrm{OAc}, \mathrm{R}_{3}=\mathrm{OH}$

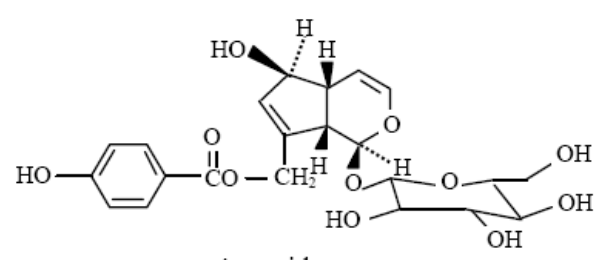

Agnuside<smiles>CC(C)c1cc2c(cc1O)[C@]1(C)CCCC(C)[C@H]1CC2=O</smiles>

Sugiol

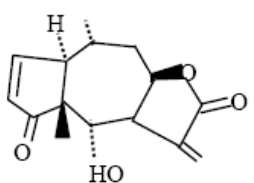

Helenalin

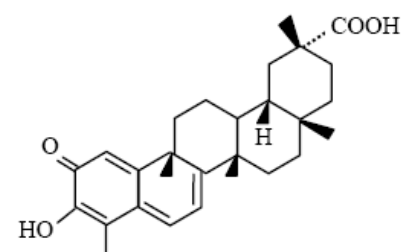

Celastrol

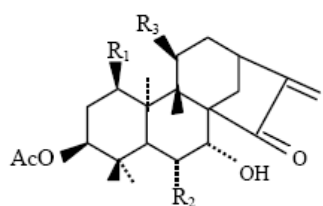

Akurane diterpenoids $1, \mathrm{R}_{1}=\mathrm{OH}, \mathrm{R}_{2}=\mathrm{H}, \mathrm{R}_{3}=\mathrm{OH}$

Akurane diterpenoids 2, $\mathrm{R}_{1}=\mathrm{OH}, \mathrm{R}_{2}=\mathrm{H}, \mathrm{R}_{3}=\mathrm{OAc}$

Akurane diterpenoids $3, \mathrm{R}_{1}=\mathrm{OH}, \mathrm{R}_{2}=\mathrm{O}, \mathrm{R}_{3}=\mathrm{OAc}$

Akurane diterpenoids 4, $\mathrm{R}_{1}=\mathrm{H}, \mathrm{R}_{2}=\mathrm{R}_{3}=\mathrm{OH}$

Akurane diterpenoids 5, $\mathrm{R}_{1}=\mathrm{R}_{2}=\mathrm{OH}, \mathrm{R}_{3}=\mathrm{OAc}$
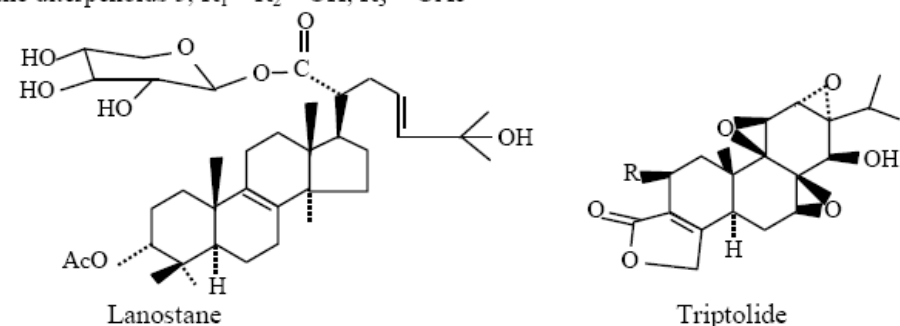

Triptolide

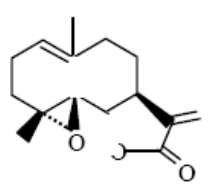

Parthenolide

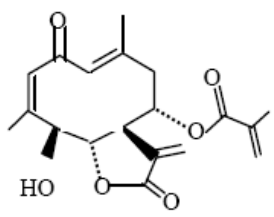

Molephantin

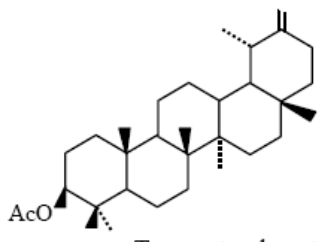

Taraxasteryl acetate<smiles>[R][C@]1(CC/C=C/C)C(=C)C(=O)O[C@@H]1/C=C/C(C)CC</smiles>

Costunolide, $\mathrm{R}_{1}=\mathrm{H}$

7-hydroxycostunolide, $\mathrm{R}_{1}=\mathrm{OH}$

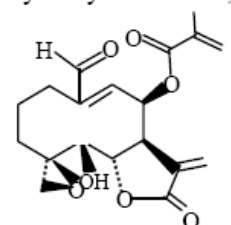


Table 2. Phytochemicals with anti-inflammatory effects and their clinical efficiencies.

\begin{tabular}{|c|c|c|c|}
\hline Herbal formulation/Compound & Indication & Clinical efficiency & References \\
\hline Curcumin & Antirheumatic & - Exerted an antirheumatic activity comparable to that of phenylbutazone & {$[184]$} \\
\hline $\begin{array}{l}\text { Active constituents of honeysuckle (Lonicera japonica) } \\
\text { stem }\end{array}$ & Anti-inflammatory and analgesic effect & $\begin{array}{l}\text { - Prevented croton oil induced-mice ear edema } \\
\text { - Inhibited arachidonic acid-induced mice ear edema } \\
\text { - Inhibited writhing reaction in mice induced by acetic acid }\end{array}$ & {$[185]$} \\
\hline $\begin{array}{l}\text { Cocoa extracts containing polyphenols enriched with } \\
\text { procyanidins }\end{array}$ & $\begin{array}{l}\text { COX and/or lipooxygenase (LOX) modulators, NO or } \\
\text { NO-synthase modulators, as non-steroidal } \\
\text { anti-inflammatory agents, platelet aggregation } \\
\text { modulators, antioxidants, inhibitors of oxidative DNA } \\
\text { damage and DNA topoisomerase II inhibitor }\end{array}$ & $\begin{array}{l}\text { - Inhibition of the COX-1 and COX-2 activities from ram seminal vesicle and } \\
\text { sheep placenta } \\
\text { - Inhibition of DNA topoisomerase II } \\
\text { - Effect on LPS-induced nitrite production by } \gamma \text {-interferon-primed } \\
\text { monocytes/macrophages } \\
\text { - Effective on cancer cells such as: KB Nasopharyngeal/HeLa cell line, } \\
\text { HCT-116 cell line, ACHN renal cell line, A-549 lung cell line, SK-5 } \\
\text { melanoma cell line, MCF-7 breast cell line, CCRF-CEM T-cell leukemia cell } \\
\text { line, MDA MB231 breast cell line, PC-3 prostate cancer cell line, Hela } \\
\text { cervical cancer cell line, SKBR-3 breast cancer cell line, CRFK normal kidney } \\
\text { cell line, MDCK normal kidney line, canine GH normal kidney cell line }\end{array}$ & {$[186]$} \\
\hline $\begin{array}{l}\text { Composition comprising: Ajuga turkestanica, Panax } \\
\text { quinquefolius, Rhodiola rosea root, Glycyrrhiza glabra, } \\
\text { Morinda citrifolia fruit, Uncaria tomentosa inner bark, } \\
\text { Capsicum frutescens, chondroitin sulfate, Curcuma } \\
\text { longa, Dioscorea villosa, glucosamine sulfate, } \\
\text { Harpagophytum procumbens and Tribulus terrestris }\end{array}$ & $\begin{array}{l}\text { Treating arthritis and its symptoms, rheumatoid arthritis } \\
\text { and osteoarthritis as well as any inflammatory condition } \\
\text { of the joints and their symptoms, pain swelling, heat, } \\
\text { redness and limitation of movement }\end{array}$ & $\begin{array}{l}\text { - The formulation is revealed to be an excellent alternative for the handling of } \\
\text { osteoarthritic patients with femoropatteral knee, chondromalacia and } \\
\text { meniscopathy }\end{array}$ & {$[187]$} \\
\hline $\begin{array}{l}\text { Synergistic mixture of standardized Boswellia serrata } \\
\text { extract, glucosamine salts, and curcuminoids. The } \\
\text { composition optionally containing bromelain, chondroitin, } \\
\text { methylsulphonylmethane, resveratrol, extracts of white } \\
\text { willow and ginger, and quercetin. }\end{array}$ & $\begin{array}{l}\text { Treating and controlling inflammatory diseases, } \\
\text { preventing and curing cancer }\end{array}$ & - Protective effect on adjuvant induced arthritis in winstar albino rats & {$[188]$} \\
\hline
\end{tabular}


Table 2. Cont

\begin{tabular}{|c|c|c|c|}
\hline Herbal formulation/Compound & Indication & Clinical efficiency & References \\
\hline $\begin{array}{l}\text { Extracts of Vitex leucoxylon and its constituents: } \\
\text { corosolic acid, agnuside and 6-O-caffeoylarbutin }\end{array}$ & $\begin{array}{l}\text { Inflammatory diseases, diabetic conditions, liver } \\
\text { disorders and free radical mediated diseases }\end{array}$ & $\begin{array}{l}\text { - Anti-inflammatory activity by preventing carrageenin induced paw } \\
\text { edema in albino wistar rats }\end{array}$ & {$[189]$} \\
\hline $\begin{array}{l}\text { Carotenoids, and xanthophyll carotenoids, or analogs or } \\
\text { derivatives of astaxanthin, lutein, zeaxanthin, lycoxanthin, } \\
\text { lycophyll, or lycopene }\end{array}$ & $\begin{array}{l}\text { Reduce the adverse side effects associated with } \\
\text { administration of COX-2 selective inhibitor drugs. } \\
\text { Reduce peroxidation of low density lipoprotein (LDL) } \\
\text { and other lipids in the serum and plasma cell membranes, } \\
\text { and reduce the incidence of deleterious clinical } \\
\text { cardiovascular events of subjects undergoing COX-2 } \\
\text { selective inhibitor drug therapy }\end{array}$ & $\begin{array}{l}\text { - Inhibition of the superoxide anion } \\
\text { - Decrease of the lag time for LDL conjugated diene formation and } \\
\text { increase of the levels of thiobarbituric-acid-reactive-substances (TBARS) } \\
\text { - Increase of isoprostane formation from lipid vesicles enriched with } \\
\text { arachidonic acid } \\
\text { - Increase in electron density associated with the upper hydrocarbon core } \\
\text { of the membrane }\end{array}$ & {$[190]$} \\
\hline $\begin{array}{l}\text { Two herbal compositions. The first composition } \\
\text { comprises Radix Clematidis, Radix Angelicae } \\
\text { Pubescentis, Rhizoma et Radix Notopterygii, Radix } \\
\text { Saposhnikoviae, and Radix Gentianae Macrophyllae. } \\
\text { The second composition comprises Rhizoma Chuanxiong, } \\
\text { Radix Angelicae Sinensis, Cortex Eucommiae, and } \\
\text { Radix Achyranthis Bidentataeas }\end{array}$ & $\begin{array}{l}\text { Preventive and therapeutic effects on alleviating } \\
\text { symptoms associated with inflammatory and rheumatic } \\
\text { diseases }\end{array}$ & $\begin{array}{l}\text { - Effective on patients with rheumatoid arthritis and lack severe side } \\
\text { effects }\end{array}$ & {$[191]$} \\
\hline $\begin{array}{l}\text { [5-hydroxy-7-methoxy-2-(4'-methoxyphenyl\}-4-oxo- } \\
\text { 4H-chromen-8-yl] sulfonic acid monoester obtainable } \\
\text { by extraction of plant material selected from Sidastrum } \\
\text { acuminatum, Sidastrum burrerense, Sidastrum E.G. } \\
\text { Baker, Sidastrum kicranthum, Sidastrum lodiegense, } \\
\text { Sidastrum multiflorum, Sidastrum micranthum, } \\
\text { Sidastrum paniculatum, Sidastrum strictum, Sidastrum } \\
\text { tehuacanum or Sidastrum quinquenervium }\end{array}$ & Inhibits the arachidonic acid cascade & $\begin{array}{l}\text { - Antiinflammatory properties keratinocyte monolayer PGE } 2 \text { model } \\
\text { - Induction of gene expression by transglutaminase which plays a crucial } \\
\text { role in the formation of jacket surrounding the keratinocytes }\end{array}$ & {$[192]$} \\
\hline Oil-soluble licorice extract & $\begin{array}{l}\text { Inhibitory effect on: hyaluronidase activity, } \\
\text { hexosaminidase release, platelet aggregation, and } \\
\text { phospholipase A2 activity, and which is suitably used } \\
\text { especially as an external preparation for skin }\end{array}$ & $\begin{array}{l}\text { - Inhibitory effect on hyaluronidase activity of bovine testis } \\
\text { - Inhibitory effect on hexosaminidase release from rat basophilic leukemia } \\
\text { cells - Inhibitory effect on rabbit platelet aggregation } \\
\text { - Inhibitory effect on phospholipase A2 activity of rat leukemia cells }\end{array}$ & {$[193]$} \\
\hline
\end{tabular}


Table 2. Cont.

\begin{tabular}{|c|c|c|c|}
\hline Herbal formulation/Compound & Indication & Clinical efficiency & References \\
\hline Extracts or fractions of Aphanamixis polystachya & Diseases mediated by 5 -lipoxygenase enzyme & $\begin{array}{l}\text { - Inhibition of 5-Lipoxygenase activity } \\
\text { - Inhibition of tyrosinase activity } \\
\text { - Anti-oxidant and anti-inflammatory activities by acting on the following } \\
\text { target molecules : nitrite, TNF- } \alpha \text {, IL-1 } \beta \text { and the levels of lipid peroxidation } \\
\text { and glutathoine in the liver of Freund complete adjuvant induced arthritis } \\
\text { model of Sprague Dawley rats }\end{array}$ & {$[194]$} \\
\hline Extracts and fractions from Hypericum gentianoides & $\begin{array}{l}\text { Inhibition of inflammation, PGE2-mediated disease, } \\
\text { disorder or condition, a COX-mediated disease, disorder } \\
\text { or condition, or an infection of HIV }\end{array}$ & $\begin{array}{l}\text { - Reduced LPS-induced COX-2 enzyme in RAW } 264.7 \text { macrophages } \\
\text { - Reduced LPS-induced PGE2 in RAW } 264.7 \text { macrophages } \\
\text { - Reduced HIV infection in vitro }\end{array}$ & {$[195]$} \\
\hline $\begin{array}{l}\text { Compositions containing one or more of a flavone or } \\
\text { flavonoid glycoside a non-bovine heavily sulfated } \\
\text { proteoglycan, an unrefined olive kernel extract, a } \\
\text { hexosamine sulfate, a histamine-1 and histamine-3 } \\
\text { receptor agonist, an antagonist of CRH, a long-chain } \\
\text { unsaturated fatty acid, a phospholipid, Krill oil, a } \\
\text { polyamine, glutiramer acetate and interferon }\end{array}$ & $\begin{array}{l}\text { Treatment of inflammatory conditions. Inhibitors of mast } \\
\text { cell activation and secretion in the brain as in multiple } \\
\text { sclerosis }\end{array}$ & $\begin{array}{l}\text { - Increased the absorption of a proteoglycan (chondroitin sulfate) from the } \\
\text { intestine into the general circulation in Sprague-Dawley rats }\end{array}$ & {$[196]$} \\
\hline Berry extract containing stable anthocyanin & Treating inflammation, oxidative damage, or cancer & $\begin{array}{l}\text { - Inhibition of proliferation of HT-29 human colorectal cancer cells } \\
\text { - Ihibition of IL-12 release from murine dendritic cells }\end{array}$ & {$[197]$} \\
\hline Free-B-Ring flavonoids from Scutellaria baicalensis & Treatment of COX-2 mediated diseases and conditions & - Inhibition of COX-1 of THP-1 cells and COX- 2 of HOSC cells & {$[198]$} \\
\hline
\end{tabular}


The inflammatory process can be initiated by various inflammatory stimuli including viruses, chemicals, and reactive oxygen/nitrogen species, which subsequently increases the synthesis and secretion of proinflammatory cytokines. Moreover, the unchecked activation of NF- $\mathrm{B} / \mathrm{AP}-1$ and the production of TNF- $\alpha$ signaling have provided compelling evidence about the critical role for these factors in coupling inflammation and many chronic diseases. Phytochemicals have been shown to modulate various points in these inflammatory processes [6]. These modulations serve as controlling points where the amplification of the inflammatory processes can be disconnected and thereby reduce subsequent diseases risk.

\subsection{Allergy}

The allergic process has an important inflammatory component. Hypersensitivity reactions can be divided into four types:

Type I: Called immediate or anaphylactic hypersensitivity mediated by IgE. Mast cells and basophils play a central role in immediate allergic inflammation through releasing chemical mediators such as histamine and cysteinyl leukotrienes, cytokines and chemokines. The reaction may involve skin (eczema), eyes (conjunctivitis), nasopharynx (rhinitis), bronchopulmonary tissues (asthma) and gastrointestinal tract (gastroenteritis).

Type II: Known as antibody-mdiated cytotoxicity mediated by antibodies of the IgM or IgG classes and complement. Antibodies directed against cell surface antigens causes cell damage such as hemolytic disease of the newborn (Rh disease) and myasthenia gravis (MG).

Type III: Known as immune complex hypersensitivity mediated by IgG or IgM classes. The reaction may be general (serum sickness) or may involve individual organs including skin (systemic lupus erythematosus), joints (rheumatoid arthritis) or other organs.

Type IV: Known as cell mediated or delayed type hypersensitivities. These reactions are mediated by $\mathrm{CD} 4+\mathrm{T}$ cells, and involved in the pathogenesis of many autoimmune diseases (multiple sclerosis). Another form of delayed hypersensitivity is contact dermatitis (poison ivy).

Therapeutic intervention in allergic disease has thus commonly focused on suppressing $\operatorname{IgE}$ production and blocking the action of histamine, thus regulating the expression and/or release of cytokines, chemokines, adhesion molecules, and or/inflammatory mediators. Below (Tables 3 and 4) are summarized some of the most studied and well-known phytochemicals with anti-allergic effects and their mode of action. Here, too, several other reports demonstrating the similar results are not represented. 
Table 3. Anti-allergic activities of phytochemicals.

\begin{tabular}{|c|c|c|c|c|}
\hline $\begin{array}{l}\text { Target } \\
\text { pathway }\end{array}$ & Effects & Compounds & Mechanism of action & Ref. \\
\hline \multirow{15}{*}{$\begin{array}{l}\text { Effect on IgE- } \\
\text { mediated } \\
\text { Hypersensitivity } \\
\text { (Type I) }\end{array}$} & \multirow{9}{*}{$\begin{array}{l}\text { Inhibition of } \\
\text { chemical } \\
\text { mediator } \\
\text { release and } \\
\text { cytokine } \\
\text { production by } \\
\text { mast, basophil } \\
\text { or T cells }\end{array}$} & Luteolin, quercetin, baicalein & $\begin{array}{l}\text { Inhibited the release of histamine, } \\
\text { leukotrienes and prostaglandin } \mathrm{D}_{2} \\
\text { Inhibited IgE-mediated TNF- } \alpha \text { and IL- } 6 \\
\text { production }\end{array}$ & [199] \\
\hline & & $\begin{array}{l}\text { Luteolin, quercetin, baicalein, } \\
\text { apigenin }\end{array}$ & $\begin{array}{l}\text { Inhibited the p44/42 MAPK } \\
\text { phosphorylation in response to } \\
\text { crosslinkage of FceRI }\end{array}$ & {$[200]$} \\
\hline & & Tetrandrine & $\begin{array}{l}\text { Suppression of prostaglandin and } \\
\text { leukotriene generation }\end{array}$ & {$[201]$} \\
\hline & & $\begin{array}{l}\text { Coixol, pseudoephedrine, } \\
\text { mallotophilippen A and B }\end{array}$ & Inhibited the release of histamine & [202-204] \\
\hline & & $\begin{array}{l}\text { Apigenin, luteolin, 3.6- } \\
\text { dihydroxy flavones, fisetin, } \\
\text { kaempferol, quercetin, } \\
\text { myricetin }\end{array}$ & $\begin{array}{l}\text { Inhibition of the hexosaminidase release } \\
\text { Suppression of cysteinyl leukotriene } \\
\text { synthesis }\end{array}$ & {$[205]$} \\
\hline & & Flavone, quercetin & $\begin{array}{l}\text { Inhibition of transport ATPase in } \\
\text { histamine secretion }\end{array}$ & {$[206,207]$} \\
\hline & & Isoquercitrin & $\begin{array}{l}\text { Inhibited carbachol and leukotriene } \mathrm{D}_{4} \\
\text { production }\end{array}$ & [208] \\
\hline & & $\begin{array}{l}\text { Cirsiliol (3',4',5-trihydroxy- } \\
\text { 6,7-dimethoxy flavone) }\end{array}$ & $\begin{array}{l}\text { Suppressed cysteinyl leukotrienes } \\
\text { release }\end{array}$ & {$[80]$} \\
\hline & & $\begin{array}{l}\text { Ayanin, luteolin, apigenin, } \\
\text { diosmetin, fisetin, ombuin, } \\
\text { quercetin, kaempferol (other } \\
\text { compounds see Table 1) }\end{array}$ & $\begin{array}{l}\text { Suppression of IL-4 synthesis (other } \\
\text { cytokines see table 1) }\end{array}$ & [209] \\
\hline & \multirow{6}{*}{$\begin{array}{l}\text { Inhibition of } \\
\text { signal } \\
\text { transduction } \\
\text { and gene } \\
\text { expression in } \\
\text { mast, basophil } \\
\text { or T cells }\end{array}$} & $\begin{array}{l}\text { Mallotophilippen A and B } \\
\text { (other compounds see Table 1) }\end{array}$ & $\begin{array}{l}\text { Inhibited iNOS gene expression (other } \\
\text { enzymes see table 1) }\end{array}$ & [204] \\
\hline & & Luteolin, apigenin, fisetin & Suppressed $\mathrm{CD}_{40}$ ligand expression & {$[209,210]$} \\
\hline & & Nobiletin & Reduced eotaxin expression & [211] \\
\hline & & Luteolin, apigenin, fisetin & Inhibited AP-1 and NFAT activation & {$[210]$} \\
\hline & & Dietary polyphenols & Interfer with activated T-helper 2 & [212] \\
\hline & & Quercetin, provinol, flavin-7 & $\begin{array}{l}\text { Anti-inflammatory effects in } \\
\text { experimental allergic asthma }\end{array}$ & [213-215] \\
\hline \multirow[b]{2}{*}{$\begin{array}{l}\text { Effect on } \\
\text { cell-mediated } \\
\text { hypersensitivity } \\
\text { (type IV) }\end{array}$} & \multirow[b]{2}{*}{$\begin{array}{l}\text { Preventing } \\
\text { contact } \\
\text { dermatitis }\end{array}$} & $\begin{array}{l}\text { Polyphenol (extract from the } \\
\text { bark of Acacia mearnsii) }\end{array}$ & $\begin{array}{l}\text { Inhibited itching in atopic dermatitis by } \\
\text { preventing the skin from drying }\end{array}$ & {$[216]$} \\
\hline & & $\begin{array}{l}\text { Polyphenols and anthocyanins } \\
\text { derived from Vaccinium } \\
\text { uliginosum } \mathrm{L}\end{array}$ & $\begin{array}{l}\text { Improve atopic dermatitis disease in } \\
\text { mice by reducing the Th2/Th1 ratio, IL- } \\
4 \text { and IL-13 (as Th2 cytokines), IFN- } \gamma \text {, } \\
\text { and IL-12 (as a Th1 cytokine) in spleens } \\
\text { Decreased gene expression, such as IL- } \\
4 \text {, IL-5, CCR3, eotaxin-1, IL-12, IFN- } \gamma \text {, } \\
\text { MCP-1, and IL-17, and suppressed Th } 17\end{array}$ & [217] \\
\hline
\end{tabular}


Table 3. Cont.

\begin{tabular}{|c|c|c|c|c|}
\hline $\begin{array}{l}\text { Target } \\
\text { pathway }\end{array}$ & Effects & Compounds & Mechanism of action & Ref. \\
\hline $\begin{array}{l}\text { Attenuating } \\
\text { autoimmune } \\
\text { disorders }\end{array}$ & $\begin{array}{l}\text { Improving } \\
\text { multiple } \\
\text { sclerosis (MS) } \\
\text { disease }\end{array}$ & $\begin{array}{l}\text { Dietary polyphenols, } \\
\text { carotenoids, curcumin }\end{array}$ & $\begin{array}{l}\text { Inhibited neuroinflammation in MS } \\
\text { Inhibited the differentiation and } \\
\text { expansion of Th17 cells in circulation } \\
\text { induced by inflammatory cascade; } \\
\text { Enhanced the expression of ZO-1; } \\
\text { Down-regulated expression of CXC } \\
\text { chemokines and receptor; } \\
\text { Decreased Th17 cells to transmigrate } \\
\text { across the blood brain barrier and the } \\
\text { inhibition of autoreactive T cells } \\
\text { transmigration can reduce } \\
\text { neuroinflammation; } \\
\text { Blocked IL17 and others, which lead to } \\
\text { centtral system nervous tissue } \\
\text { destruction in MS }\end{array}$ & [218-220] \\
\hline
\end{tabular}

Table 4. Phytochemicals with anti-allergic effects and their clinical efficiencies.

\begin{tabular}{|c|c|c|c|}
\hline Herbal formulations/Compounds & Indication & Clinical efficiency & Ref. \\
\hline $\begin{array}{l}\text { Seeds of Cucurbita moschata and flowers of } \\
\text { Carthamus tinctorius and at least one crude } \\
\text { drug selected from Plantago asiatica, } \\
\text { Lonicera japonica, Glycyrrhiza uralensis, } \\
\text { Coix lachrymal-jobi var. ma-yuen, Zingiber } \\
\text { officinale, Curcuma longa, Curcuma } \\
\text { zedoaria and Artemisia argyi. }\end{array}$ & $\begin{array}{l}\text { Prevention or } \\
\text { therapy of pollen } \\
\text { allergy, allergic } \\
\text { rhinitis, atopic } \\
\text { dermatitis, asthma } \\
\text { or urticaria }\end{array}$ & $\begin{array}{l}\text { Animal trials: Inhibiting the production } \\
\text { of total IgE antibodies in the blood of } \\
\text { mice sensitized with cedar pollen Human } \\
\text { trials: Therapeutic effects on patients } \\
\text { suffering from cedar pollen allergy }\end{array}$ & [221] \\
\hline $\begin{array}{l}\text { Formulation(s) comprises of Tinospora } \\
\text { cardifolia, Piper longum, Albizia lebbeck } \\
\text { and Curcuma amada }\end{array}$ & Treatment of allergy & $\begin{array}{l}\text { Decreased the histamine release (mast } \\
\text { cell degranulation) in rats-Reduced lipid } \\
\text { peroxidation and superoxide dismutase } \\
\text { activity, and increased catalase activity in } \\
\text { tissues (liver, kidney and heart) rats }\end{array}$ & [222] \\
\hline $\begin{array}{l}\text { The composition comprises at least one of } \\
\text { the following ingredients: luteolin from } \\
\text { Perilla leaf or seed, Cinnamon, Kiwi, Picao } \\
\text { preto, Hesperidin, Acerola cherry, Guaco, } \\
\text { Holy Basil, Kakadu, Solamum, Rosmarinic } \\
\text { acid, Tinospora and Aframomum }\end{array}$ & $\begin{array}{l}\text { Inhibits and/or } \\
\text { mitigates an allergic } \\
\text { response }\end{array}$ & $\begin{array}{l}\text { Inhibition of the IgE secretion by U266 } \\
\text { human myeloma cells-Reduction of the } \\
\text { IgE receptor expression by RBL-2H3 } \\
\text { cells-Inhibiting or preventing the release } \\
\text { of mediators such as histamine, PGD } 2 \\
\text { and LTC4 by RBL-2H3 cells }\end{array}$ & [223] \\
\hline 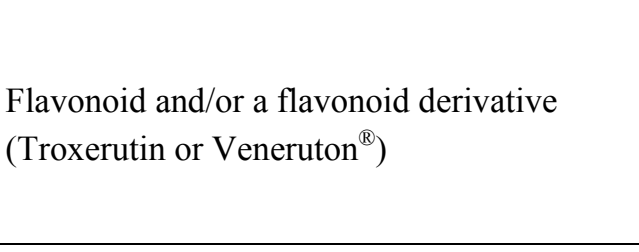 & $\begin{array}{l}\text { Treating symptoms } \\
\text { of common cold, } \\
\text { allergic rhinitis and } \\
\text { infections relating to } \\
\text { the respiratory tract }\end{array}$ & $\begin{array}{l}\text { Showed success results on different } \\
\text { patients suffering from common cold } \\
\text { symptoms-Reduced the symptom score } \\
\text { after treatment of patients suffering from } \\
\text { allergic airway conditions }\end{array}$ & [224] \\
\hline Kaempferol, apigenin & $\begin{array}{l}\text { Treatment of contact } \\
\text { dermatis }\end{array}$ & $\begin{array}{l}\text { Inhibited iNOS induction produced in } \\
\text { contact dermatitis }\end{array}$ & [225] \\
\hline Dehydrocorydaline & $\begin{array}{l}\text { Treatment of } \\
\text { hypersensivities } \\
\text { reactions }\end{array}$ & $\begin{array}{l}\text { Inhibited the induction phase of picryl } \\
\text { chloride-induced contact dermatitisin } \\
\text { mice }\end{array}$ & [226] \\
\hline
\end{tabular}


Despite the promising use of plant products for medicinal purposes for the evidences discussed above, it is worth noting that many of the dietary phytochemicals or natural products are not without cytotoxic effect and can originate various allergic reactions. The well known allergenic phytoconstituents are sesquiterpene lactones and furanocoumarins. Many of plants containing sesquiterpene lactones cause allergic contact dermatitis and effective treatments are scarce. Other natural products such as flavonoids [227], alkaloids [228,229], and terpenoids [230,231] can also cause allergic reactions. Phenolics such as: anethol, atranorin, catechols, cinnamon, cinnamic derivatives, benzoic acid, curcumin, eugenol, isoeugenol, litreol, ginkgolic acid, resorcinols, oak moss resin, tertiaery-butylhydroquinone, urushiol, usnic acid. Alkaloids such as: atropine, pilocarpine, quinine, thebaine, codeine, and terpenoids such as: abietic acid, alantolactone, artesunate, asiaticoside, asiatic and madecassic acids, carvone, citral, $\beta$-cyclocostunolide, dehydroabietic acid, eucalyptol, farnesol, geraniol, limonene, $\alpha$-pinene, phellandrene, linalool, menthol, myrrh, parthenolide, polygodial, sesquiterpenes, sesquiterpenes, thymol (reviewed in Rios et al. [232]). While flavonoids are only weakly antigenic and usually do not induce immune reactions after consumption or therapeutic application, antibodies against flavonoids have been found in human blood [227]. Adverse side effects of polyphenol intake on cardiovascular diseases have been also reported. A high consumption of polyphenol ( $2 \mathrm{~g}$ chlorogenic acid per day during 1 week) significantly increased homocysteinemia [233,234]. The consumption of tea has been associated with a higher bone mineral density [235]. A recent randomized crossover trial [236] revealed that moderate consumption of red wine reduced erythrocyte superoxide dismutase activity. Another randomized double-blind, placebo-controlled trial showed that the combination of vitamin $\mathrm{C}$ and grape-seed polyphenols increases blood pressure [237].

\section{Conclusions}

Phytochemicals show both anti-inflammatory and anti-allergic activities in vitro and in vivo. Several cellular action mechanisms are proposed to explain their mode of action. Any single mechanism could not explain all of their in vivo activities. They probably have multiple cellular mechanisms acting on multiple sites of cellular machinery. The continual efforts will provide new insight into the anti-inflammatory and anti-allergic activities of phytochemicals, and eventually lead to development of a new class of anti-inflammatory and anti-allergic agents. However, the concern and difficulties related to the investigation of herbal medicines have precluded the financial incentives that could be provided to pharmaceutical industries. As a function of such difficulties, few herbal drugs have been studied adequately and well-controlled double-blind clinical trials to prove their safety and efficacy have been lacking. The trend today, especially in an industrial setting, is to seek bioactive compounds from plants that will serve as lead compounds for synthetic or semisynthetic development, and knowledge of the main pharmacologically active plant compounds is an essential requirement to standardize procedures for obtaining herbal remedies in order to replace crude products with modern pharmacological formulations. 


\section{Acknowledgements}

The authors acknowledge the funding of this study by Mohammad Hussein Al-Amoudi Chair for Diabetic Foot Research and also the Deanship of Scientific Research, at King Abdulaziz University.

\section{References}

1 Fabricant, D.S.; Farnsworth, N.R. The value of plants used in traditional medicine for drug discovery. Environ. Health Perspect. 2001, 109, 69-75.

2 Jachak, S.M.; Saklani, A. Challenges and opportunities in drug discovery from plants. Curr. Sci. 2007, 92, 1251-1257.

3 Harvey, A. Strategies for discovering drugs from previously unexplored natural products. Drug Discov. Today 2000, 5, 294-300.

4 Bakhotmah, B.A.; Alzahrani, H.A. Self-reported use of complementary and alternative medicine (CAM) products in topical treatment of diabetic foot disorders by diabetic patients in Jeddah, Western Saudi Arabia. BMC Res. Notes 2010, 2010, 254.

5 Bellik, Y.; Hammoudi, S.M.; Abdellah, F.; Iguer-Ouada, M.; Boukraâ, L. Phytochemicals to prevent inflammation and allergy. Recent Pat. Inflamm. Allergy Drug Discov. 2012, 6, 147-158.

6 Kim, Y.S.; Young, M.R.; Bobe, G.; Colburn, N.H.; Milner, J.A. Bioactive food components, inflammatory targets, and cancer prevention. Cancer Prev. Res. 2009, 2, 200-208.

7 Gautam, R.; Jachak, S.M. Recent developments in anti-infammatory natural products. Med. Res. Rev. 2009, 29, 767-820.

8 Calixto, J.B.; Otuki, M.F.; Santos Adair, R.S. Anti-inflammatory compounds of plant origin. Part I. Action on arachidonic acid pathway, nitric oxide and nuclear factor $\kappa \mathrm{B}(\mathrm{NF}-\kappa \mathrm{B})$. Planta Med. 2003, 69, 973-983.

9 Akiyama, H.; Barger, S.; Barnum, S.; Bradt, B.; Bauer, J.; Cole, G.M.; Cooper, N.R.; Eikelenboom, P.; Emmerling, M.; Fiebich, B.L.; et al. Inflammation and Alzheimer's disease. Neurobiol. Aging 2000, 21, 383-421.

10 Libby, P.; Ridker, P.M.; Maseri, A. Inflammation and atherosclerosis. Circulation 2002, 105, 1135-1143.

11 Cragg, G.M.; Newman, D.J.; Snader, K.M. Natural products in drug discovery and development. J. Nat. Prod. 1997, 60, 52-60.

12 Brito, F.A.; Lima, L.A.; Ramos, M.F.S.; Nakamura, M.J.; Cavalher-Machado, S.C.; Siani, A.C.; Henriques, M.G.M.O.; Sampaio, A.L.F. Pharmacological study of anti-allergic activity of Syzygium cumini (L.) Skeels. Braz. J. Med. Biol. Res. 2007, 40, 105-115.

13 Nettis, E.; Colanardi, M.C.; Ferrannini, A.; Tursi, A. Antihistamines as important tools for regulating inflammation. Curr. Med. Chem. Anti Inflamm. Anti Allergy Agents 2005, 4, 81-89.

14 Tewtrakul, S.; Itharat, A. Anti-allergic substances from the rhizomes of Dioscorea membranacea. Bioorg. Med. Chem. 2006, 14, 8707-8711.

15 Croteau, R.; Kutchan, T.M.; Lewis, N.G. Natural Products (Secondary Metabolites). In Biochemistry \& Molecular Biology of Plants; Buchanan, B., Gruissem, W., Jones, R., Eds.; Wiley: Hoboken, NJ, USA, 2000; Chapter 24, pp. 1250-1318. 
16 Liu, R.H. Potential synergy of phytochemicals in cancer prevention: Mechanism of action. J. Nutr. 2004, 134, 3479S-3485S.

17 Calabrese, V.; Cornelius, C.; Dinkova-Kostova, A.T.; Iavicoli, I.; Di Paola, R.; Koverech, A.; Cuzzocrea, S.; Rizzarelli, E.; Calabrese, E.J. Cellular stress responses, hormetic phytochemicals and vitagenes in aging and longevity. Biochim. Biophys. Acta. 2012, 1822, 753-783.

18 Nichenametla, S.N.; Taruscio, T.G.; Barney, D.L.; Exon, J.H. A Review of the effects and mechanisms of polyphenolics in cancer. Crit. Rev. Food Sci. Nutr. 2006, 46, 161-183.

19 Arya, V.; Arya, M.L. A Review on anti-inflammatory plant barks. Int. J. Pharm.Tech. Res. 2011, 3, 899-908.

20 Vauzour, D. Dietary polyphenols as modulators of brain functions: Biological actions and molecular mechanisms underpinning their beneficial effects. Oxid. Med. Cell. Longev. 2012, doi:10.1155/2012/914273.

21 Alía, M.; Ramos, S.; Mateos, R.; Granado-Serrano, A.B.; Bravo, L.; Goya, L. Quercetin protects human hepatoma HepG2 against oxidative stress induced by tert-butyl hydroperoxide. Toxicol. Appl. Pharmacol. 2006, 212, 110-118.

22 Pandey, K.B.; Rizvi, S.I. Protective effect of resveratrol on markers of oxidative stress in human erythrocytes subjected to in vitro oxidative insult. Phytother. Res. 2010, 24, S11-S14.

23 Scharf, G.; Prustomersky, S.; Knasmuller, S.; Schulte-Hermann, R.; Huber, W.W. Enhancement of glutathione and g-glutamylcysteine synthetase, the rate limiting enzyme of glutathione synthesis, by chemoprotective plant-derived food and beverage components in the human hepatoma cell line HepG2. Nutr. Cancer 2003, 45, 74-83.

24 Gulcin, I. Antioxidant properties of resveratrol: A structure-activity insight. Innovat. Food Sci. Emerg Tech. 2010, 11, 210-218.

25 Fki, I.; Sahnoun, Z.; Sayadi, S. Hypocholesterolemic effects of phenolic extracts and purified hydroxytyrosol recovered from olive mill wastewater in rats fed a cholesterol-rich diet. J. Agric. Food. Chem. 2007, 55, 624-631.

26 Du, Y.; Guo, H.; Lou, H. Grape seed polyphenols protect cardiac cells from apoptosis via induction of endogenous antioxidant enzymes. J. Agric. Food. Chem. 2007, 55, 1695-1701.

27 Rodrigo, R.; Miranda, A.; Vergara, L. Modulation of endogenous antioxidant system by wine polyphenols in human disease. Clin. Chim. Acta 2011, 412, 410-424.

28 Leung, H.W.; Kuo, C.L.; Yang, W.H.; Lin, C.H.; Lee, H.Z. Antioxidant enzymes activity involvement in luteolin-induced human lung squamous carcinoma $\mathrm{CH} 27$ cell apoptosis. Eur. J. Pharmacol. 2006, 534, 12-18.

29 Vanhees, K.; van Schooten, F.J.; Moonen, E.J.; Maas, L.M.; van Waalwijk van Doorn-Khosrovani, S.B.; Godschalk, R.W.L. Maternal intake of quercetin during gestation alters ex vivo benzo[a] pyrene metabolism and DNA adduct formation in adult offspring. Mutagenesis 2012, 27, 445-451.

30 Shen, S.Q.; Zhang, Y.; Xiang, J.J.; Xiong, C.L. Protective effect of curcumin against liver warm ischemia/reperfusion injury in rat model is associated with regulation of heat shock protein and antioxidant enzymes. World J. Gastroenterol. 2007, 13, 1953-1961.

31 Hong, J.; Smith, T.J.; Ho, C.T.; August, D.A.; Yang, C.S. Effects of purified green and black tea polyphenols on cyclooxygenase- and lipoxygenase-dependent metabolism of arachidonic acid in human colon mucosa and colon tumor tissues. Biochem. Pharmacol. 2001, 62, 1175-1183. 
32 Park, J.B. Effects of typheramide and alfrutamide found in Allium species on cyclooxygenases and lipoxygenases. J. Med. Food 2011, 14, 226-231.

33 Schewe, T.; Sadik, C.; Klotz, L.O.; Yoshimoto, T.; Kuhn, H.; Sies, H. Polyphenols of cocoa: Inhibition of mammalian 15-lipoxygenase. Biol. Chem. 2001, 382, 1687-1696.

34 Fernandez, M.A.; de las Heras, B.; Garcia, M.D.; Saenz, M.T.; Villar, A. New insights into the mechanism of action of the anti-inflammatory triterpene lupeol. J. Pharm. Pharmacol. 2001, 53, 1533-1539.

35 Rangkadilok, N.; Sitthimonchai, S.; Worasuttayangkurn, L.; Mahidol, C.; Ruchirawat, M.; Satayavivad, J. Evaluation of free radical scavenging and antityrosinase activities of standardized longan fruit extract. Food Chem. Toxicol. 2007, 45, 328-336.

36 Leopoldini, M.; Russo, N.; Toscano, M. The molecular basis of working mechanism of natural polyphenolic antioxidants. Food Chem. 2011, 125, 288-306.

37 Cadenas, S.; Barja, G. Resveratrol, melatonin, vitamin E, and PBN protect against renal oxidative DNA damage induced by the kidney carcinogen KBrO3. Free Radic. Biol. Med. 1999, 26, 1531-1537.

38 Hanaski, Y.; Ogawa, S.; Fukui, S. The correlation between active oxygen scavenging and antioxidative effects of flavonoids. Free Radic. Biol. Med. 1994, 16, 845-850.

39 Mascio, P.D.; Murphy, M.E.; Sies, H. Antioxidant defense systems: The role of carotenoids, tocopherols, and thiols. Am. J. Clin. Nutr. 1991, 53, 194S-200S.

40 Chen, Y.; Tsai, Y.H.; Tseng, S.H. The potential of tetrandrine as a protective agent for ischemic stroke. Molecules 2011, 16, 8020-8032.

41 Srinivasan, M.; Sudheer, A.R.; Pillai, K.R.; Kumar, P.R.; Sudhakaran, P.R.; Menon, V.P. Lycopene as a natural protector against gamma-radiation induced DNA damage, lipid peroxidation and antioxidant status in primary culture of isolated rat hepatocytes in vitro. Biochim. Biophys. Acta 2007, 1770, 659-665.

42 Yang, S.C.; Huang, C.C.; Chu, J.S.; Chen, J.R. Effects of $\beta$-carotene on cell viability and antioxidant status of hepatocytes from chronically ethanol-fed rats. Br. J. Nutr. 2004, 92, 209-215.

43 Manna, S.K. Double-edged sword effect of biochanin to inhibit nuclear factor kappaB: Suppression of serine/threonine and tyrosine kinases. Biochem. Pharmacol. 2012, 15, 1383-1392.

44 Trevillyan, J.M.; Lu, Y.L.; Atluru, D.; Phillips, C.A.; Bjorndahl, J.M. Differential inhibition of $\mathrm{T}$ cell receptor signal transduction and early activation events by selective inhibitor of protein-tyrosine kinase. J. Immunol. 1990, 145, 3223-3230.

45 Comalada, M.; Ballester, I.; Bailon, E.; Sierra, S.; Xaus, J.; Galvez, J.; de Medina, F.S.; Zarzuelo, A. Inhibition of pro-inflammatory markers in primary bone marrow-derived mouse macrophages by naturally occurring flavonoids: Analysis of the structure-activity relationship. Biochem. Pharmacol. 2006, 72, 1010-1021.

46 Pečivová, J.; Mačičková, T.; Sviteková, K.; Nosá, R. Quercetin inhibits degranulation and superoxide generation in PMA stimulated neutrophils. Interdiscip. Toxicol. 2012, 5, 81-83.

47 Kanashiro, A.; Souza, J.G.; Kabeya, L.M.; Azzolini, A.E.; Lucisano-Valim, Y.M. Elastase release by stimulet neutrophils inhibited by flavonoids: Importance of the catechol group. Z. Naturforsch. C 2007, 62, 357-361. 
48 Tordera, M.; Ferrandiz, M.L.; Alcaraz, M.J. Influence of anti-inflammatory flavonoids on degranulation and arachidonic acid release in rat neutrophils. Z. Naturforsch. C 1994, 49, 235-240.

49 Berton, G.; Schneider, C.; Romeo, D. Inhibition by quercetin of activation of polymorphonuclear leukocyte functions. Stimulus-specific effects. Biochim. Biophys. Acta 1980, 595, 47-55.

50 Lee, T-P.; Matteliano, M.L.; Middletone, E. Effect of quercetin on human polymorphonuclear leukocyte lysosomal enzyme release and phospholipid metabolism. Life Sci. 1982, 31, 2765-2774.

51 Selloum, L.; Bouriche, H.; Tigrine, C.; Boudoukha, C. Anti-inflammatory effect of rutin on rat paw oedema, and on neutrophils chemotaxis and degranulation. Exp. Toxicol. Pathol. 2003, 54, 313-318.

52 Lanni, C.; Becker, E.L. Inhibition of neutrophil phospholipase $\mathrm{A}_{2}$ by $p$-bromophenylacyl bromide, nordihydroguaiaretic acid, 5,8,11,14-eicosatetrayenoic acid and quercetin. Int. Arch. Allergy Appl. Immunol. 1985, 76, 214-217.

53 Chiou, Y.L.; Lin, S.R.; Hu, W.P.; Chang, L.S. Quercetin modulates activities of Taiwan cobra phospholipase A2 via its effects on membrane structure and membrane-bound mode of phospholipase A2. J. Biosci. 2012, 37, 277-87.

54 Gil, B.; Sanz, M.J.; Terencio, M.C.; Ferrandiz, M.L.; Bustos, G.; Paya, M.; Gunasegaran, R.; Alcaraz, M.J. Effects of flavonoids on Naja naja and human recombinant synovial phospholipase $\mathrm{A}_{2}$ and inflammatory responses in mice. Life Sci. 1994, 54, PL333-PL338.

55 Chang, H.W.; Baek, S.H.; Chung, K.W.; Son, K.H.; Kim, H.P.; Kang, S.S. Inactivation of phospholipase $\mathrm{A}_{2}$ by naturally occurring biflavonoid, ochnaflavone. Biochem. Biophys. Res. Commun. 1994, 205, 843-849.

56 Gil, B.; Sanz, M.J.; Terencio, M.C.; Gunasegaran, R.; Paya, M.; Alcaraz, M.J. Morelloflavone, a novel biflavonoid inhibitor of human secretory phospholipase $A_{2}$ with anti-inflammatory activity. Biochem. Pharmacol. 1997, 53,733-740.

57 Baek, S.H.; Yun, S.S.; Kwon, T.K.; Kim, J.R.; Chang, H.W.; Kwak, J.Y.; Kim, J.H.; Kwun, K.B. The effects of two new antagonists of secretory PLA 2 on TNF- $\alpha$, iNOS, and COX-2 expression in activated macrophages. Shock 1999, 12, 473-478.

58 Hong, J.; Bose, M.; Ju, J.; Ryu, J.H.; Chen, X.; Sang, S.; Lee, M.J.; Yang, C.S. Modulation of arachidonic acid metabolism by curcumin and related beta diketone derivatives: Effects on cytosolic phospholipase A(2), cyclooxygenases and 5-lipoxygenase. Carcinogenesis 2004, 25, 1671-1679.

59 Kwak, W.-J.; Moon, T.C.; Lin, C.X.; Rhyn, H.G.; Jung, H.; Lee, E.; Kwon, D.Y.; Son, K.H.; Kim, H.P.; Kang, S.S.; et al. Papyriflavonol A from Broussonetia papyrifera inhibits the passive cutaneous anaphylaxis reaction and has a secretory phospholipase $\mathrm{A}_{2}$-inhibitory activity. Biol. Pharm. Bull. 2003, 26, 299-302.

60 Bauman, J.; von Bruchhausen, F.V.; Wurm, G. Flavonoids and related compounds as inhibitors of arachidonic acid peroxidation. Prostaglandins 1980, 20, 627-639.

61 Landorfi, R.; Mower, R.L.; Steiner, M. Modification of platelet function and arachidonic acid metabolism by biflavonoids. Structure-activity relations. Biochem. Pharmacol. 1984, 33, 1525-1530.

62 Akhtar, N.; Haqqi, T.M. Epigallocatechin-3-gallate suppresses the global interleukin-1betainduced inflammatory response in human chondrocytes. Arthritis Res. Ther. 2011, 13, R93. 
63 Kimura, Y.; Okuda, H.; Nomura, T.; Fukai, T.; Arichi, S. Effects of phenolic constituents from the mulberry tree on arachidonate metabolism in rat platelets. J. Nat. Prod. 1986, 49, 639-644.

64 Lin, C.N.; Lu, C.M.; Lin, H.C.; Fang, S.C.; Shieh, B.J.; Hsu, M.F.; Wang, J.P.; Ko, F.N.; Teng, C.M. Novel antiplatelet constituents from Formosan Moraceous plants. J. Nat. Prod. 1996, 59, 834-838.

65 Gerhauser, C.; Klimo, K.; Heiss, E.; Neumann, I.; Gamal-Eldeen, A.; Knauft, J.; Liu, G.Y.; Sitthimonchai, S.; Frank, N. Mechanism-based in vitro screening of potential cancer chemopreventive agents. Mutat. Res. 2003, 523-524, 163-172.

66 Csaki, C.; Keshishzadeh, N.; Fischer, K.; Shakibaei, M. Regulation of inflammation signaling by resveratrol in human chondrocytes in vitro. Biochem. Pharmacol. 2008, 75, 677-687.

67 Ferrandiz, M.L.; Ramachandran Nair, A.G.; Alcaraz, M.J. Inhibition of sheep platelet arachidonate metabolism by flavonoids from Spanish and Indian medicinal herbs. Pharmazie 1990, 45, 206-208.

68 You, K.M.; Jong, H.; Kim, H.P. Inhibition of cyclooxygenase/lipoxygenase from human platelets by polyhydroxylated/methoxylated flavonoids isolated from the several medicinal plants. Arch. Pharm. Res. 1999, 22, 18-24.

69 Chi, Y.S.; Jong, H.; Son, K.H.; Chang, H.W.; Kang, S.S.; Kim, H.P. Effects of naturally occurring prenylated flavonoids on arachidonic acid metabolizing enzymes: Cylooxygenases and lipoxygenases. Biochem. Pharmacol. 2001, 62, 1185-1191.

70 Moon, T.C.; Murakami, M.; Kudo, I.; Son, K.H.; Kim, H.P.; Kang, S.S.; Chang, H.W. A new class of Cox-2 inhibitor, rutaecarpine from Evoida rutaecarpa. Inflamm. Res. 1999, 48, 621-625.

71 Hou, C.-C.; Chen, Y.-P.; Wu, J.-H.; Huang, C.-C.; Wang, S.-Y.; Yang, N.-S.; Shyur, L.-F. A Galactolipid possesses novel cancer chemopreventive effects by suppressing inflammatory mediators and mouse B16 melanoma. Cancer Res. 2007, 67, 6907-6915.

72 Noreen, Y.; Serrano, G.; Perera, P.; Bohlin, L. Flavan-3-ols isolated from some medicinal plants inhibiting COX-1 and COX-2 catalysed prostaglandin biosynthesis. Planta Med. 1998, 64, 520-524.

73 Jang, D.S.; Cuendet, M.; Hawthorne, M.E. Prenylated flavonoids of the leaves of Macaranga conifera with inhibitory activity against cyclooxygenase-2. Phytochemistry 2002, 61, 867-872.

74 Likhiwitayawuid, K.; Sawasdee, K.; Kirtikara, K. Flavonoids and stilbenoids with COX-1 and COX-2 inhibitory activity from Dracaena loureiri. Planta Med. 2002, 68, 841-843.

75 Sailer, E.R.; Subramanian, L.R.; Rall, B.; Hoernlein, R.F.; Ammon, H.P.; Safayhi, H. Acetyl-11keto-beta-boswellic acid (AKBA): Structure requirements for binding and 5-lipoxygenase inhibitory activity. Br. J. Pharmcol. 1996, 117, 615-618.

76 Safayhi, H.; Boden, S.E.; Schweizer, S.; Ammon, H.P. Concentration-dependent potentiating and inhibitory effects of Boswellia extracts on 5-lipoxygenase product formation in stimulated PMNL. Planta Med. 2000, 66, 110-113.

77 Prieto, J.M.; Giner, R.M.; Recio, M.M.C.; Schinella, G.; Manez, S.; Rios, J.L. Diphyllin acetylapioside, a 5-lipoxygenase inhibitor from Haplophyllum hispanicum. Planta Med. 2002, 68, 359-360.

78 Nakadate, T.; Yamamoto, S.; Aizu, E.; Kato, R. Effects of flavonoids and antioxidants on 12-O-tetradecanoylphorbol 13-acetate induced epidermal ornithine decarboxylase induction and tumor promotion in relation to lipoxygenase inhibition by these compounds. Gann 1984, 75, $214-222$. 
79 Laughton, M.J.; Evans, P.J.; Moroney, M.A.; Hoult, J.R.S.; Halliwell, B. Inhibition of mammalian 5-lipoxygenase and cyclooxygenase by flavonoids and phenolic dietary additives. Biochem. Pharmacol. 1991, 42, 1673-1681.

80 Kim, H.P.; Indu, M.; Iversen, L.; Ziboh, V.A. Effects of naturally occurring flavonoids and biflavonoids on epidermal cyclooxygenase and lipoxygenase from guinea-pigs. Prostaglandins Leukot. Essent. Fatty Acids 1998, 58, 17-24.

81 Yoshimoto, T.; Furukawa, M.; Yamamoto, S.; Horie, T.; Watanabe-Kohno, S. Flavonoids: Potent inhibitors of arachidonate 5-lipoxygenase. Biochem. Biophys. Res. Commun. 1983, 116, 612-618.

82 Reddy, G.R.; Ueda, N.; Hada, T.; Sackeyfio, A.C.; Yamamoto, S.; Hana, Y. A prenylatedflavone, artonin E, as arachidonate 5-lipoxygenase inhibitor. Biochem. Pharmacol. 1991, 41, 115-118.

83 Kinaci, M.K.; Erkasap, N.; Kucuk, A.; Koken, T.; Tosun, M. Effects of quercetin on apoptosis, $\mathrm{NF}-\kappa \mathrm{B}$ and NOS gene expression in renal ischemia/reperfusion injury. Exp. Ther. Med. 2012, 3, 249-254.

84 Wang, Y.; Zhu, Y.; Gao, L.; Yin, H.; Xie, Z.; Wang, D.; Zhu, Z.; Han, X. Formononetin attenuates IL- $1 \beta$-induced apoptosis and NF- $\kappa \mathrm{B}$ activation in INS-1 cells. Molecules 2012, 17 , 10052-10064.

85 Sadowska-Krowicka, H.; Mannick, E.E.; Oliver, P.D.; Sandoval, M.; Zhang, X.J.; Eloby-Childess, S.; Clark, D.A.; Miller, M.J. Genistein and gut inflammation: Role of nitric oxide. Proc. Soc. Exp. Biol. Med. 1998, 217, 351-357.

86 Soliman, K.F.A.; Mazzio, E.A. In vitro attenuation of nitric oxide production in C6 astrocyte cell culture by various dietary compounds. Proc. Soc. Exp. Biol. Med. 1998, 218, 390-397.

87 Kim, H.; Kim, Y.S.; Kim, S.Y.; Suk, K. The plant flavonoid wogonin suppresses death of activated C6 rat glial cells by inhibiting nitric oxide production. Neurosci. Lett. 2001, 309, 67-71.

88 Kao, T.K.; Ou, Y.C.; Raung, S.L.; Lai, C.Y.; Liao, S.L.; Chen, C.J. Inhibition of nitric oxide production by quercetin in endotoxin/cytokine-stimulated microglia. Life Sci. 2010, 86, 315-321.

89 Fu, P.K.; Wu, C.L.; Tsai, T.H.; Hsieh, C.L. Anti-Inflammatory and anticoagulative effects of paeonol on LPS-induced acute lung injury in rats. Evid. Based Complement. Alternat. Med. 2012, doi:10.1155/2012/837513.

90 Geng, Y.; Zhang, B.; Lotz, M. Protein tyrosine kinase activation is required for lipopolysaccharide induction of cytokines in human blood monocytes. J. Immunol. 1993, 151, 6692-6700.

91 Yoon, J.S.; Chae, M.K.; Lee, S.Y.; Lee, E.J. Anti-inflammatory effect of quercetin in a whole orbital tissue culture of Graves' orbitopathy. Br. J. Ophthalmol. 2012, 96, 1117-1121.

92 Jang, S.; Dilger, R.N.; Johnson, R.W. Luteolin inhibits microglia and alters hippocampal-dependent spatial working memory in aged mice. J. Nutr. 2010, 140, 1892-1898.

93 Lin, N.; Sato, T.; Takayama, Y.; Mimaki, Y.; Sashida, Y.; Yano, M.; Ito, A. Novel anti-inflammatory actions of nobiletin, a citrus polymethoxy flavonoid, on human synovial fibroblasts and mouse macrophages. Biochem. Pharmacol. 2003, 65, 2065-2071.

94 Krakauer, T. The polyphenol chlorogenic acid inhibits staphylococcal exotoxin-induced inflammatory cytokines and chemokines. Immunopharmacol. Immunotoxicol. 2002, 24, 113-119. 
95 Hong, J.J.; Jeong, T.S.; Choi, J.H.; Park, J.H.; Lee, K.Y.; Seo, Y.J.; Oh, S.R.; Oh, G.T. Hematein inhibits tumor necrotic factor-alpha-induced vascular cell adhesion molecule-1 and NF-kappaBdependent gene expression in human vascular endothelial cells. Biochem. Biophys. Res. Commun. 2001, 281, 1127-1133.

96 Jeong, H.J.; Koo, H.N.; Na, H.J.; Kim, M.S.; Hong, S.H.; Eom, J.W.; Kim, K.S.; Shin, T.Y.; Kim, H.M. Inhibition of TNF-alpha and IL-6 production by Aucubin through blockade of NF-kappaB activation RBL-2H3 mast cells. Cytokine 2002, 18, 252-259.

97 An, S.J.; Pae, H.O.; Oh, G.S.; Choi, B.M.; Jeong, S.; Jang, S.I.; Oh, H.; Kwon, T.O.; Song, C.E.; Chung, H.T. Inhibition of TNF-alpha, IL-1beta, and IL-6 productions and NF-kappa B activation in lipopolysaccharide-activated RAW 264.7 macrophages by catalposide, an iridoid glycoside isolated from Catalpa ovata G. Don (Bignoniaceae). Int. Immunopharmacol. 2002, 2, 1173-1181.

98 Choi, H.S.; Kim, H.S.; Min, K.R.; Kim, Y.; Lim, H.K.; Chang, Y.K.; Chung, M.W. Antiinflammatory effects of fangchinoline and tetrandrine. J. Ethnopharmacol. 2000, 69, 173-179.

99 Onai, N.; Tsunokawa, Y.; Suda, M.; Watanabe, N.; Nakamura, K.; Sugimoto, Y.; Kobayashi, Y. Inhibitory effects of bisbenzylisoquinoline alkaloids on induction of proinflammatory cytokines, interleukin-1 and tumor necrosis factor-alpha. Planta Med. 1995, 61, 497-501

100 Kiraz, S.; Ertenli, I.; Arici, M.; Calguneri, M.; Haznedaroglu, I.; Celik, I.; Pay, S.; Kirazli, S. Effects of colchicine on inflammatory cytokines and selectins in familial Mediterranean fever. Clin. Exp. Rheumatol. 1998, 16, 721-724.

101 Chiou, W.F.; Peng, C.H.; Chen, C.F.; Chou, C.J. Anti-inflammatory properties of piperlactam $\mathrm{S}$ : Modulation of complement 5a-induced chemotaxis and inflammatory cytokines production in macrophages. Planta Med. 2003, 69, 9-14.

102 Sun, J.; Han, J.; Zhao, Y.; Zhu, Q.; Hu, J. Curcumin induces apoptosis in tumor necrosis factor-alpha-treated HaCaT cells. Int. Immunopharmacol. 2012, 13, 170-174.

103 Ding, J.; Polier, G.; Köhler, R.; Giaisi, M.; Krammer, P.H.; Li-Weber, M. Wogonin and related natural flavones overcome tumor necrosis factor-related apoptosis-inducing ligand (TRAIL) protein resistance of tumors by down-regulation of c-FLIP protein and up-regulation of TRAIL receptor 2 expression. J. Biol. Chem. 2012, 2, 641-649.

104 Wadsworth, T.L.; McDonald, T.L.; Koop, D.R. Effects of Ginkgo biloba extract (EGb 761) and quercetin on lipopolysaccharide-induced signaling pathways involved in the release of tumor necrosis factor- $\alpha$. Biochem. Pharmacol. 2001, 62, 963-974.

105 Morikawa, K.; Nonaka, M.; Narahara, M.; Torii, I.; Kawaguchi, K.; Yoshikawa, T.; Kumazawa, Y.; Morikawa, S. Inhibitory effect of quercetin on carrageenan-induced inflammation in rats. Life Sci. 2003, 74, 709-721.

106 Dien, M.V.; Takahashi, K.; Mu, M.M.; Koide, N.; Sugiyama, T.; Mori, I.; Yoshida, T.; Yokochi, T. Protective effect of wogonin on endotoxin-induced lethal shock in D-galactosamine-sensitized mice. Microbiol. Immunol. 2001, 45, 751-756.

107 Takahashi, K.; Morikawa, A.; Kato, Y.; Sugiyama, T.; Koide, N.; Mu, M.M.; Yoshida, T.; Yokochi, T. Flavonoids protect mice from two types of lethal shock induced by endotoxin. FEMS Immunol. Med. Microbiol. 2001, 31, 29-33.

108 Shin, D.K.; Kim, M.H.; Lee, S.H.; Kim, T.H.; Kim, S.Y. Inhibitory effects of luteolin on titanium particle-induced osteolysis in a mouse model. Acta Biomater. 2012, 8, 3524-3351. 
109 Kim, J.E.; Son, J.E.; Jang, Y.J.; Lee, D.E.; Kang, N.J.; Jung, S.K.; Heo, Y.S.; Lee, K.; Lee, H.J. Luteolin, a novel natural inhibitor of TPL2 kinase, inhibits tumor necrosis factor- $\alpha$-induced cyclooxygenase-2 expression in JB6 mouse epidermis cells. J. Pharmacol. Exp. Ther. 2011, 338, 1013-1022.

110 Ueda, H.; Yamazaki, C.; Yamazaki, M. A hydroxyl group of flavonoids affects oral anti-inflammatory activity and inhibition of systemic tumor necrosis factor- $\alpha$ production. Biosci. Biotechnol. Biochem. 2004, 68, 119-125.

111 Li, Y.C.; Yeh, C.H.; Yang, M.L.; Kuan, Y.H. Luteolin suppresses inflammatory mediator expression by blocking the Akt/NFkB pathway in acute lung injury induced by lipopolysaccharide in mice. Evid. Based Complement. Alternat. Med. 2012, doi:10.1155/2012/383608.

112 Kumazawa, Y.; Kawaguchi, K.; Takimoto, H. Immunomodulating effects of flavonoids on acute and chronic inflammatory responses caused by tumor necrosis factor $\alpha$. Curr. Pharm. Des. 2006, $12,4271-4279$.

113 Okabe, S.; Suganuma, M.; Imayoshi, Y.; Taniguchi, S.; Yoshida, T.; Fujiki, H. New TNF $\alpha$ releasing inhibitors, geraniin and corilagin, in leaves of Acer nikoense, Megusurino-Ki. Biol. Pharm. Bull. 2001, 10, 1145-1148.

114 Cho, J.Y.; Park, J.; Yoo, E.S.; Yoshikawa, K.; Baik, K.U.; Lee, J.; Park, M.H. Inhibitory effect of lignans from the rhizomes of Coptis japonica var. dissecta on tumor necrosis factor-alpha production in lipopolysaccharide-stimulated RAW264.7 cells. Arch. Pharmacol. Res. 1998, 21, $12-16$.

115 Cho, J.Y.; Baik, K.U.; Yoo, E.S.; Yoshikawa, K.; Park, M.H. In vitro anti-inflammatory effects of neolignan woorenosides from the rhizomes of Coptis japonica. J. Nat. Prod. 2000, 63, 1205-1209.

116 Hart, P.H.; Brand, C.; Carson, C.F.; Riley, T.V.; Prager, R.H.; Finlay-Jones, J.J. Terpinen-4-ol, the main component of the essential oil of Malaleuca alternifolia (tea tree oil), suppresses inflammatory mediator production by activated human monocytes. Inflamm. Res. 2000, 49, 619-626.

117 Soares, M.B.; Bellintani, M.C.; Ribeiro, I.M.; Tomassini, T.C.; Ribeiro dos Santos, R. Inhibition of macrophage activation and lipopolysaccaride-induced death by seco-steroids purified from Physalis angulata L. Eur. J. Pharmacol. 2003, 459, 107-112.

118 Lin, N.; Sato, T.; Ito, A. Triptolide, a novel diterpenoid triepoxide from Tripterygium wilfordii Hook. F., suppresses the production and gene expression of pro-matrix metalloproteinases 1 and 3 and augments those of tissue inhibitors of metalloproteinases 1 and 2 in human synovial fibroblasts. Arthritis Rheum. 2001, 44, 193-2200.

119 Liacini, A.; Sylvester, J.; Zafarullah, M. Triptolide suppresses proinflammatory cytokine-induced matrix metalloproteinase and aggrecanase-1 gene expression in chondrocytes. Biochem. Biophys. Res. Commun. 2005, 327, 320-327.

120 Ha, S.K.; Moon, E.; Ju, M.S.; Kim, D.H.; Ryu, J.H.; Oh, M.S.; Kim, S.Y. 6-Shogaol, a ginger product, modulates neuroinflammation: A new approach to neuroprotection. Neuropharmacology 2012, 63, 211-223.

121 Shany, S.; Levy, Y.; Lahav-Cohen, M. The effects of 1 $\alpha, 24(S)$-dihydroxyvitamin $\mathrm{D}_{2}$ analog on cancer cell proliferation and cytokine expression. Steroids 2001, 66, 319-325. 
122 Ono, M.; Tanaka, N.; Moriyasu, T. Anti-inflammatory action of cepharanthine ointment ingredient in experimental animals: Studies on chronic inflammation and TNF-alpha production. Ensho 1994, 14, 425-429.

123 Parmely, M.J.; Zhou, W.W.; Edwards, C.K., III; Borcherding, D.R.; Silverstein, R.; Morrison, D.C. Adenosine and a related carbocyclic nucleoside analogue selectively inhibit tumor necrosis factor-alpha production and protect mice against endotox challenge. J. Immunol. 1993, 151, 389-396.

124 Gerritsen, M.E.; Carley, W.W.; Ranges, G.E.; Shen, C.P.; Phan, S.A.; Ligon, G.F.; Perry, C.A. Flavonoids inhibit cytokine-induced endothelial cell adhesion protein gene expression. Am. J. Pathol. 1995, 147, 278-292.

125 Nakamura, N.; Hayasaka, S.; Zhang, X.Y.; Nagaki, Y.; Matsumoto, M.; Hayasaka, Y.; Terasawa, K. Effects of baicalin, baicalein and wogonin on interleukin- 6 and interleukin- 8 expression, and nuclear factor- $\kappa \mathrm{B}$ binding activities induced by interleukin- $1 \beta$ in human retinal pigmant epithelial cell line. Exp. Eye Res. 2003, 77, 195-202.

126 Atluru, D.; Jackson, T.M.; Atluru, S. Genistein, a selective protein tyrosine kinase inhibitor, inhibits interleukin-2 and leukotriene $\mathrm{B}_{4}$ production from human mononuclear cells. Clin. Immunol. Immunopathol. 1991, 59, 379-387.

127 Hernandez, V.; del Carmen Recio, M.; Manez, S.; Prieto, J.M.; Giner, R.M.; Rios, J.L. A mechanistic approach to the in vivo anti-inflammatory activity of sesquiterpenoid compounds isolated from Inula viscosa. Planta Med. 2001, 67, 726-731.

128 Danz, H.; Stoyanova, S.; Thomet, O.A.; Simon, H.U.; Dannhardt, G.; Ulbrich, H.; Hamburger, M. Inhibitory activity of tryptanthrin on prostaglandin and leukotriene synthesis. Planta Med. 2002, $68,875-880$.

129 Bermejo, B.P.; Abad Martinez, M.J.; Silvan Sen, A.M.; Sanz Gomez, A.; Fernandez Matellano, L.; Sanchez Contreras, S.; Diaz Lanza, A.M. In vivo and in vitro anti-inflammatory activity of saikosaponins. Life Sci. 1998, 63, 1147-1156.

130 Bermejo, B.P.; Diaz Lanza, A.M.; Silvan Sen, A.M.; de Santos Galindez, J.; Fernandez Matellano, L.; Sanz Gomez, A.; Abad Martinez, M.J. Effects of some iridoids from plant origin on arachidonic acid metabolism in cellular systems. Planta Med. 2000, 66, 324-328.

131 Giner-Larza, E.M.; Manez, S.; Giner, R.M.; Recio, M.C.; Prieto, J.M.; Cerda-Nicolas, M.; Rios, J.L. Anti-inflammatory triterpenes from Pistacia terebinthus galls. Planta Med. 2002, 68, 311-315.

132 Diaz Lanza, A.M.; Abad Martinez, M.J.; Fernandez Matellano, L.; Recuero Carretero, C.; Villaescusa Castillo, L.; Silvan Sen, A.M.; Bermejo Benito, P. Lignan and phenylpropanoid glycosides from Phillyrea latifolia and their in vitro anti-inflammatory activity. Planta Med. 2001, 67, 219-223.

133 Kim, Y.P.; Yamada, M.; Lim, S.S.; Lee, S.H.; Ryu, N.; Shin, K.H. Inhibition of tectorigenin and tectoridin of prostaglandin $\mathrm{E}_{2}$ production and cyclooxygenase-2 induction in rat peritoneal macrophages. Biochim. Biophys. Acta 1999, 1438, 399-407.

134 Kim, Y.P.; Lee, E.B.; Kim, S.Y.; Li, D.; Ban, H.S.; Lim, S.S.; Shin, K.H.; Ohuchi, K. Inhibition of prostaglandin E2 production by platycodin D isolated from the root of Platycodon grandiflorum. Planta Med. 2001, 67, 362-364. 
135 Hong, C.H.; Noh, M.S.; Lee, W.Y.; Lee, S.K. Inhibitory effects of natural sesquiterpenoids isolated from the rhizomes of Curcuma zedoaria on prostaglandin E2 and nitric oxide production. Planta Med. 2002, 68, 545-547.

136 Woo, H.G.; Lee, C.H.; Noh, M.S.; Lee, J.J.; Jung, Y.S.; Baik, E.J.; Moon, C.H.; Lee, S.H. Rutaecarpine, a quinazolinocarboline alkaloid, inhibits prostaglandin production in RAW264.7 macrophages. Planta Med. 2001, 67, 505-509.

137 Nakajima, T.; Imanishi, M.; Yamamoto, K.; Cyong, J.C.; Hirai, K. Inhibitory effect of baicalein, a flavonoid in Scutellaria root, on eotaxin production by human dermal fibroblasts. Planta Med. 2001, 67, 132-135.

138 Chi, Y.S.; Cheon, B.S.; Kim, H.P. Effect of wogonin, a plant flavones from Scutellaria radix, on the suppression of cyclooxygenase and the induction of inducible nitric oxide synthase in lipopolysaccharide-treated RAW 264.7 cells. Biochem. Pharmacol. 2001, 61, 1195-1203.

139 Kim, H.K.; Cheon, B.S.; Kim, Y.H.; Kim, S.Y.; Kim, H.P. Effects of naturally occurring flavonoids on nitric oxide production in the macrophage cell line RAW 264.7 and their structural-activity relationships. Biochem. Pharmacol. 1999, 58, 759-765.

140 Liang, Y.C.; Huang, Y.T.; Tsai, S.H.; Lin-Shiau, S.Y.; Chen, C.F.; Lin, J.K. Suppression of inducible cyclooxygenase and inducible nitric oxide synthase by apigenin and related flavonoids in mouse macrophages. Carcinogenesis 1999, 20, 1945-1952.

141 Murakami, A.; Nakamura, Y.; Torikai, K.; Tanaka, T.; Koshiba, T.; Koshimizu, K.; Kuwahara, S.; Takahashi, Y.; Ogawa, K.; Yano, M.; Tokuda, H.; et al. Inhibitory effect of citrus nobiletin on phorbol ester-induced skin inflammation, oxidative stress, and tumor promotion in mice. Cancer Res. 2000, 60, 5059-5066.

142 Chen, Y.C.; Yang, L.L.; Lee, T.J.F. Oroxylin A inhibition of lipopolysaccharide-induced iNOS and COX-2 gene expression via suppression of nuclear factor- $\kappa \mathrm{B}$ activation. Biochem. Pharmacol. 2000, 59, 1445-1457.

143 Raso, G.M.; Meli, R.; di Carlo, G.; Pacillio, M.; di Carlo, R. Inhibiton of inducible nitric oxide synthase and cyclooxygenase-2 expression by flavonoids in macrophage J774A.1. Life Sci. 2001, 68, 921-931.

144 Shen, S.C.; Lee, W.R.; Lin, H.Y.; Huang, H.C.; Ko, C.H.; Yang, L.L.; Chen, Y.C. In vitro and in vivo inhibitory activities of rutin, wogonin, and quercetin on lipopolysaccharide-induced nitric oxide and prostaglandin E2 production. Eur. J. Pharmacol. 2002, 446, 187-194.

145 Singh, R.; Ahmed, S.; Islam, N.; Goldberg, V.M.; Haqqi, T.M. Epigallocatechin-3-gallate inhibits interleukin-1 $\beta$-induced expression of nitric oxide synthase and production of nitric oxide in human chondrocytes. Suppression of nuclear factor $\kappa \mathrm{B}$ by degradation of the inhibitor of nuclear factor $\kappa$ B. J. Rheumatol. 2002, 46, 2079-2086.

146 Chan, M.M.; Fong, D.; Ho, C.T.; Huang, H.T. Inhibition of inducible nitric oxide synthase gene expression and enzyme activity by epigallocatechin gallate, a natural product from green tea. Biochem. Pharmacol. 1997, 54, 1281-1286.

147 Takahashi, T.; Takasuka, N.; Ligo, M.; Baba, M.; Nishino, H.; Tsuda, H. Isoliquilitigenin, a flavonoid from licorice, reduces prostaglandin $\mathrm{E}_{2}$ and nitric oxide, causes apoptosis, and suppresses aberrant crypt foci development. Cancer Sci. 2004, 95, 448-453. 
148 Kang, J.S.; Jeon, Y.J.; Kim, H.M.; Han, S.H.; Yang, K.H. Inhibition of inducible nitric-oxide synthase expression by silymarin in lipopolysaccharide-stimulated macrophages. J. Pharmacol. Exp. Ther. 2002, 302, 138-144.

149 Chan, M.M.; Huang, H.I.; Fenton, M.R.; Fong, D. In vivo inhibition of nitric oxide synthase gene expression by curcumin, a cancer preventive natural product with anti-inflammatory properties. Biochem. Pharmacol. 1998, 55, 1955-1962.

150 Hamalainen, M.; Nieminen, R.; Vuorela, P.; Heinonen, M.; Moilanen, E. Anti-inflammatory effects of flavonoids: Genistein, kaempferol, quercetin, and daidzein inhibit STAT-1 and NF-kappaBactivations, whereas flavone, isorhamnetin, naringenin, and pelargonidin inhibit only NF-kappaB activation along with theirinhibitory effect on iNOS expression and NO production in activated macrophages. Mediators Inflamm. 2007, 2007, 45673.

151 Lee, H.; Kim, Y.O.; Kim, H.; Kim, S.Y.; Noh, H.S.; Kang, S.S. Flavonoid wogonin from medicinal herb is neuroprotective by inhibiting inflammatory activation of microglia. FASEB J. 2003, 17, 1943-1944.

152 Qureshi, A.A.; Guan, X.Q.; Reis, J.C.; Papasian, C.J.; Jabre, S.; Morrison, D.C.; Qureshi, N. Inhibition of nitric oxide and inflammatory cytokines in LPS-stimulated murine macrophages by resveratrol, a potent proteasome inhibitor. Lipids Health Dis. 2012, 11, 76.

153 Wang, B.; Ma, L.; Tao, X.; Lipsky, P.E. Triptolide, an active component of the Chinese herbal remedy Tripterygium wilfordii Hook F, inhibits production of nitric oxide by decreasing inducible nitric oxide synthase gene transcription. Arthritis Rheum. 2004, 50, 2995-3003.

154 Suh, N.; Honda, T.; Finlay, H.J.; Barchowsky, A.; Williams, C.; Benoit, N.E.; Xie, Q.W.; Nathan, C.; Gribble, G.W.; Sporn, M.B. Novel triterpenoids suppress inducible nitric oxide synthase (iNOS) and inducible cyclooxygenase (COX-2) in mouse macrophages. Cancer Res. 1998, 58, 717-723.

155 Stempelj, M.; Kedinger, M.; Augenlicht, L.; Klampfer, L. Essential role of the JAK/STAT1 signaling pathway in the expression of inducible and its regulation by butyrate. J. Biol. Chem. 2007, 282, 9797-804.

156 Palombo, P.; Fabrizi, G.; Ruocco, V. Beneficial long-term effects of combined oral/topical antioxidant treatment with the carotenoids lutein and zeaxanthin on human skin: A double-blind, placebo-controlled study. Skin Pharmacol. Physiol. 2007, 20, 199-210.

157 Kang, N.J.; Shin, S.H.; Lee, H.J.; Lee, K.W. Polyphenols as small molecular inhibitors of signaling cascades in carcinogenesis. Pharmacol. Ther. 2011, 130, 310-324.

158 Hooshmand, S.; Soung do, Y.; Lucas, E.A.; Madihally, S.V.; Levenson, C.W.; Arjmandi, B.H. Genistein reduces the production of proinflammatory molecules in human chondrocytes. J. Nutr. Biochem. 2007, 18, 609-614.

159 Kwak, W.J.; Han, C.K.; Son, K.H.; Chang, H.W.; Kang, S.S.; Park, B.K.; Kim, H.P. Effects of ginkgetin from Ginkgo biloba leaves on cyclooxygenases and in vivo skin inflammation. Planta Med. 2002, 68, 316-321.

160 Mutoh, M.; Takahashi, M.; Fukuda, K.; Komatsu, H.; Enya, T.; Matsushima-Hibiya, Y.; Mutoh, H.; Sugimura, T.; Wakabayashi, K. Suppression by flavonoids of cyclooxygenase-2 promotor-dependent transcriptional activity in colon cancer cells: Structural-activity relationship. Jpn. J. Cancer Res. 2000, 91, 686-691. 
161 Chen, C.Y.; Peng, W.H.; Tsai, K.D.; Hsu, S.L. Luteolin suppresses inflammation-associated gene expression by blocking NF-kappaB and AP-1 activation pathway in mouse alveolar macrophages. Life Sci. 2007, 81, 1602-1614.

162 Wakabayashi, I.; Yasui, K. Wogonin inhibits inducible prostaglandin $\mathrm{E}_{2}$ production in macrophages. Eur. J. Pharmacol. 2000, 406, 477-481.

163 Park, B.K.; Heo, M.Y.; Park, H.; Kim, H.P. Inhibition of TPA-induced cyclooxygenase-2 and skin inflammation in mice by wogonin, a plant flavone from Scutellaria radix. Eur. J. Pharmacol. 2001, 425, 153-157.

164 Banerjee, T.; Valacchi, G.; Ziboh, V.A.; van der Vliet, A. Inhibition of TNF $\alpha$-induced cyclooxygenase-2 expression by amentoflavone through suppression of NF- $\mathrm{BB}$ activation in A549 cells. Mol. Cell. Biochem. 2002, 238, 105-110.

165 Tong, X.; Yin, L.; Joshi, S.; Rosenberg, D.W.; Giardina, C. Cyclooxygenase-2 regulation in colon cancer cells: Modulation of RNA polymerase II elongation by histone deacetylase inhibitors. J. Biol. Chem. 2005, 280, 15503-15509.

166 Subbaramaiah, K.; Michaluart, P.; Sporn, M.B.; Dannenberg, A.J. Ursolic acid inhibits cyclooxygenase-2 transcription in human mammary epithelial cells. Cancer Res. 2000, 60, 2399-2404.

167 Suksamrarn, A.; Kumpun, S.; Kirtikara, K.; Yingyongnarongkul, B.; Suksamrarn, S. Iridoids with anti-inflammatory activity from Vitex peduncularis. Planta Med. 2002, 68, 72-73.

168 Hirata, A.; Murakami, Y.; Atsumi, T.; Shoji, M.; Ogiwara, T.; Shibuya, K.; Ito, S.; Yokoe, I.; Fujisawa, S. Ferulic acid dimer inhibits lipopolysaccharide-stimulated cyclooxygenase-2 expression in macrophages. In Vivo 2005, 19, 849-853.

169 Kim, S.O.; Kundu, J.K.; Shin, Y.K.; Park, J.H.; Cho, M.H.; Kim, T.Y.; Surh, Y.J. [6]-Gingerol inhibits COX-2 expression by blocking the activation of p38 MAP kinase and NF- $\kappa \mathrm{B}$ in phorbol ester stimulated mouse skin. Oncogene 2005, 24, 2558-2567.

170 Kim, J.K.; Kim, Y.; Na, K.M.; Surh, Y.J.; Kim, T.Y. [6]-Gingerol prevents UVB-induced ROS production and COX-2 expression in vitro and in vivo. Free Radic. Res. 2007, 41, 603-614.

171 Kundu, J.K.; Shin, Y.K.; Kim, S.H.; Surh, Y.J. Resveratrol inhibits phorbol ester-induced expression of COX-2 and activation of NF- $\kappa \mathrm{B}$ in mouse skin by blocking I $\mathrm{B}$ kinase activity. Carcinogenesis 2006, 27, 1465-1474.

172 Peng, G.; Dixon, D.A.; Muga, S.J.; Smith, T.J.; Wargovich, M.J. Green tea polyphenol (-)-epigallocatechin-3-gallate inhibits cyclooxygenase-2 expression in colon carcinogenesis. Mol. Carcinog. 2006, 45, 309-319.

173 Donnelly, L.E.; Newton, R.; Kennedy, G.E.; Fenwick, P.S.; Leung, R.H.F.; Ito, K.; Russell, R.E.K.; Barnes, P.J. Anti-inflammatory effects of resveratrol in lung epithelial cells: Molecular mechanisms. Am. J. Physiol. Lung Cell. Mol. Physiol. 2004, 287, L774-L783.

174 Haridas, V.; Arntzen, C.J.; Gutterman, J.U. Avicins, a family of triterpenoid saponins from Acacia victoriae (Bentham), inhibit activation of nuclear factor-kappaB by inhibiting both its nuclear localization and ability to bind DNA. Proc. Natl. Acad. Sci. USA 2001, 98, 11557-11562.

175 Sheehan, M.; Wong, H.R.; Hake, P.W.; Malhotra, V.; O’Connor, M.; Zingarelli, B. Parthenolide, an inhibitor of the nuclear factor-kappaB pathway, ameliorates cardiovascular derangement and outcome in endotoxic shock in rodents. Mol. Pharmacol. 2002, 61, 953-963. 
176 Feng, R.; Lu, Y.; Bowman, L.L.; Qian, Y.; Castranova, V.; Ding, M. Inhibition of AP-1, NF-kB and MAPKs and induction of phase 2 detoxifying enzyme activity by chlorogenic acid. J. Biol. Chem. 2005, 280, 2888-2895.

177 Qiu, D.; Zhao, G.; Aoki, Y.; Shi, L.; Uyei, A.; Nazarian, S.; Ng, J.C.-H.; Kao, P.N. Immunosuppressant PG490 (triptolide) inhibits T-cell interleukin-2 expression at the level of purine-box/nuclear factor of activated T-cells and NFkappaB transcriptional activation. J. Biol. Chem. 1999, 274, 13443-13450.

178 Han, S.S.; Keum, Y.S.; Chun, K.S.; Surh, Y.J. Suppression of phorbol ester-induced NF-jB activation by capsaicin in cultured human promyelocytic leukemia cells. Arch. Pharm. Res. 2002, 25, 475-479.

179 Lührs, H.; Gerke, T.; Müller, J.G.; Melcher, R.; Schauber, J.; Boxberge, F.; Scheppach, W.; Menzel, T. Butyrate inhibits NF- $\kappa$ B activation in lamina propria macrophages of patients with ulcerative colitis. Scand. J. Gastroenterol. 2002, 37, 458-466.

180 Kim, J.S.; Jobin, C. The flavonoid luteolin prevents lipopolysaccharide-induced NK-kappaB signaling and gene expression by blocking I-kappaB kinase activity in intestinal epithelial cells and bone-marrow derived dendritic cells. Immunology 2005, 115, 373-387.

181 Jobin, C.; Bradham, C.A.; Russo, M.P.; Juma, B.; Narula, A.S.; Brenner, D.A.; Sartor, R.B. Curcumin blocks cytokine-mediated NF- $\mathrm{BB}$ activation and pro-inflammatory gene expression by inhibiting inhibitory factor I-кB kinase activity. J. Immunol. 1999, 163, 3474-3483.

182 Hunter, M.S.; Corley, D.G.; Carron, C.P.; Rowold, E.; Kilpatrick, B.F.; Durley, R.C. Four new clerodane diterpenes from the leaves of Casearia guianensis which inhibit the interaction of leukocyte function antigen 1 with intercellular adhesion molecule 1. J. Nat. Prod. 1997, 60, 894-899.

183 Asahina, A.; Tada, Y.; Nakamura, K.; Tamaki, K. Colchicine and griseofulvin inhibit VCAM-1 expression on human vascular endothelial cells-evidence for the association of VCAM-1 expression with microtubules. J. Dermatol. Sci. 2001, 25, 1-9.

184 Goel, A.; Kunnumakkara, A.B.; Aggarwal, B.B. Curcumin as "Curecumin": From kitchen to clinic. Biochem. Pharmacol. 2008, 75, 787-809.

185 Kwak, W.J.; Cho, Y.B.; Han, C.K.; Shin, H.J.; Ryu, K.H.; Yoo, H.; Rhee, H.I. Extraction and purification method of active constituents from stem of Lonicera japonica thunb, its usage for anti-inflammatory and analgesic drug. US20087314644, 1 January 2008.

186 Kealey, K.S.; Snyder, R.M.; Romanczyk, L.J.; Geyet, H.M.; Myers, M.E.; Whitacre, E.J.; Schmitz, H.H. Treatment of inflammation. US20080188550, 7 August 2008.

187 Olalde Rangel, J.A. Arthritis phyto-nutraceutical synergistic composition. US20087416748, 26 August 2008.

188 Gokaraju, G.R.; Gokaraju, R.R.; Gottumukkala, V.S.; Golakoti, T. Dietary supplement formulation for controlling inflammation and cancer. US20087455860, 25 December 2008.

189 Gokaraju, G.R.; Gokaraju, R.R.; Gottumukkala, V.S.; Somepalli, V. Pharmaceutically Active Extracts of Vitex Leucoxylon, a Process of Extracting the Same and a Method of Treating Diabetes and Inflammatory Diseases Therewith. US20080199543, 21 August 2008.

190 Lockwood, S.F.; Mason, P.R. Use of carotenoids and/or carotenoid derivatives/analogs for reduction/inhibition of certain negative effects of COX inhibitors. US20080293679, 27 November 2008. 
$191 \mathrm{Li}, \mathrm{Y}$. Herbal compositions for prevention and treatment of rheumatic and inflammatory diseases and method of preparing the same. US20097553506, 3 July 2009.

192 Buchholz, H.; Wirth, C.; Carola, C.; Alves Fontes, R. Flavonoid derivates. US20097588783, 15 September 2009.

193 Miyake, Y.; Yoko, I. Anti-inflammatory agent. US20100120903, 13 May 2010.

194 Gokaraju, G.R.; Gokaraju, R.R.; Golakoti, T.; Chirravuri, V.R.; Alluri, V.K.R.; Bhupathiraju, K. Use of Aphanamixis polystacha extracts or fractions against 5-lipoxygenase mediated diseases. US20100178288, 15 July 2010.

195 Hillwig, M.L. Anti-inflammatory and anti-HIV compositions and methods of use. US20107854946, 21 December 2010.

196 Theoharides, T.C. Anti-inflammatory compositions for treating multiple sclerosis. US20117906153, 15 March 2011.

197 Mumper, R.J.; Dai, J.; Gallicchio, V.S. Berry preparations and extracts. US20117964223, 21 June 2011.

198 Jia, Q.; Nichols, T.C.; Rhoden, E.E.; Walte, S. Identification of Free-B-Ring flavonoids as potent COX-2 inhibitors. US20110245333, 6 October 2011.

199 Kimata, M.; Shichijo, M.; Miura, T.; Serizawa, I.; Inagaki, N.; Nagai, H. Effects of luteolin, quercetin and baicalein on immunoglobulin E-mediated mediator release from human cultured mast cells. Clin. Exp. Allergy 2000, 30, 501-508.

200 Yano, S.; Tachibana, H.; Yamada, K. Flavones suppress the expression of the high-affinity IgE receptor Fc epsilon RI in human basophilic KU812 cells. J. Agric. Food Chem. 2005, 53, 1812-1817.

201 Wu, S.J.; Ng, L.T. Tetrandrine inhibits proinflammatory cytokines, iNOS and COX-2 expression in human monocytic cells. Biol. Pharm. Bull. 2007, 30, 59-62.

202 Otsuka, H.; Hirai, Y.; Nagao, T.; Yamasaki, K. Antiinflammatory activity of benzoxazinoids from roots of Coix lachryma-jobi var. ma-yuen. J. Nat. Prod. 1988, 51, 74-79.

203 Wang, M.; Huang, Y.J.; Zhang, T.H.; Tong, Z.Q. Anti-allergic, anti-histamine and anti-inflammatory effects of compound pseudoephedrine. J. Shenyang Pharm. Univ. 1996, 132, 129-133.

204 Daikonya, A.; Katsuki, S.; Wu, J.-B.; Kitanaka, S. Anti-allergic agents from natural sources $\left(4^{1)}\right)$ : Anti-allergic activity of new phloroglucinol derivatives from Mallotus philippensis (Euphorbiaceae). Chem. Pharm. Bull. 2002, 50, 1566-1659.

205 Cheong, H.; Ryu, S.Y.; Oak, M.H.; Cheon, S.H.; Yoo, G.S.; Kim, K.M. Studies of structure activity relationship of flavonoids for the anti-allergic actions. Arch. Pharm. Res. 1998, 21, 478-480.

206 Fewtrell, C.M.; Gomperts, B.D. Effect of flavone inhibitors on transport ATPases on histamine secretion from rat mast cells. Nature 1977, 265, 635-636.

207 Middleton, E.J.; Drzewiecki, G.; Krishnarao, D. Quercetin: An inhibitor of antigen-induced human basophil histamine release. J. Immunol. 1981, 127, 546-550.

208 Fernandez, J.; Reyes, R.; Ponce, H.; Oropeza, M.; Vancalsteren, M.R.; Jankowski, C.; Campos, M.G. Isoquercitrin from Argemone platyceras inhibits carbachol and leukotriene $\mathrm{D}_{4}$-induced contraction in guinea-pig airways. Eur. J. Pharmacol. 2005, 522, 108-115.

209 Kawai, M.; Hirano, T.; Higa, S.; Arimitsu, J.; Maruta, M.; Kuwahara, Y.; Ohkawara, T.; Hagihara, K.; Yamadori, T.; Shima, Y.; et al. Flavonoids and related compounds as anti-allergic substances Allergol. Int. 2007, 56, 113-123. 
210 Hirano, T.; Arimitsu, J.; Higa, S.; Naka, T.; Ogata, A.; Shima, Y.; Fujimoto, M.; Yamadori, T; Ohkawara, T.; Kuwabara, Y.; et al. Luteolin, a flavonoid, inhibits $\mathrm{CD}_{40}$ ligand expression by activated human basophils. Int. Arch. Allergy Immunol. 2006, 140, 150-156.

211 Wu, Y.Q.; Zhou, C.H.; Tao, J.; Li, S.N. Antagonistic effects of nobiletin, a polymethoxyflavonoid, on eosinophilic airway inflammation of asthmatic rats and relevant mechanisms. Life Sci. 2006, 78, 2689-2696.

212 Magrone, T.; Jirillo, E. Influence of polyphenols on allergic immune reactions: Mechanisms of action. Proc. Nutr. Soc. 2012, 71, 316-321.

213 Joskova, M.; Franova, S.; Sadloňova, V. Acute bronchodilator effect of quercetin in experimental allergic asthma. Bratisl. Lek. Listy 2011, 112, 9-12.

214 Fraňova, S.; Strapkova, A.; Mokry, J.; Šutovska, M.; Joškova, M.; Sadloňova, V.; Antošova, M.; Pavelčikova, D.; Fleškova, D.; Nosal'ova, G. Pharmacologic modulation of experimentally induced allergic asthma. Interdiscp. Toxicol. 2011, 4, 27-32.

215 Joskova, M.; Sadlonova, V.; Nosalova, G.; Novakova, E.; Franova, S. Polyphenols and their components in experimental allergic asthma. Adv. Exp. Med. Biol. 2013, 756, 91-98.

216 Ikarashi, N.; Sato, W.; Toda, T.; Ishii, M.; Ochiai, W.; Sugiyama, K. Inhibitory effect of polyphenol-rich fraction from the bark of Acacia mearnsii on itching associated with allergic dermatitis. Evid. Based Complement. Alternat. Med. 2012, doi:10.1155/2012/120389.

217 Kim, M.J.; Choung, S.Y. Mixture of polyphenols and anthocyanins from Vaccinium uliginosum L. alleviates DNCB-induced atopic dermatitis in NC/Nga Mice. Evid. Based Complement Alternat. Med. 2012, doi:10.1155/2012/461989.

218 Riccio, P.; Rossano, R.; Liuzzi, G.M. May diet and dietary supplements improve the wellness of multiple sclerosis patients? A molecular approach. Autoimmune Dis. 2010, 2010, 249842.

219 Riccio, P. The molecular basis of nutritional intervention inmultiplesclerosis: A narrative review. Complement. Ther. Med. 2011, 19, 228-237.

220 Xie, L.; Li, X.K.; Takahara, S. Curcumin has bright prospects for the treatment of multiplesclerosis. Int. Immunopharmacol. 2011, 11, 323-330.

221 Yoshida, S. Preventive or therapeutic agent for pollen allergy, allergic rhinitis, atopic dermatitis, asthma or urticaria, or health food for prevention or improvement or reduction of symptoms thereof. US20046811796, 2 November 2004.

222 Palpu, P.; Rao, C.V.; Rawat, A.K.S.; Ojha, S.K.; Reddy, G.D. Anti-allergic herbal formulation. US20087344739, 18 March 2008.

223 Menon, G.R.; Fast, D.J.; Krempin, D.W.; Goolsby, J.N. Anti-Allergy composition and related method. US20087384654, 10 June 2008.

224 Frimman Berg, K. Method of treating symptoms of common cold, allergic rhinitis and infections relating to the respiratory tract. US20118003688, 23 August 2011.

225 Olszanecki, R.; Gebska, A.; Kozlovski, V.I.; Gryglewski, R.J. Flavonoids and nitric oxide synthase. J. Physiol. Pharmacol. 2002, 53, 571-584.

226 Matsuda, H.; Tokuoka, K.; Wu, J.; Shiomoto, H.; Kubo, M. Inhibitory effects of dehydrocorydaline isolated from Corydalis Tuber against type I-IV allergic models. Biol. Pharm. Bull. 1997, 20, 431-434. 
227 Havsteen, B.H. The biochemistry and medical significance of the flavonoids. Pharmacol. Ther. 2002, 96, 67-202.

228 Carboni, G.P.; Contri, P.; Davalli, R. Allergic contact dermatitis from apomorphine. Contact Derm. 1997, 36, 177-178.

229 Waclawski, E.R.; Aldridge, R. Occupational dermatitis from thebaine and codeine. Contact Derm. 1995, 33, 51.

230 Tanaka, S.; Otsuki, T.; Matsumoto, Y.; Hayakawa, R.; Sugiura, M. Allergic contact dermatitis from enoxolone. Contact Derm. 2001, 44, 192.

231 Basketter, D.A.; Wright, Z.M.; Colson, N.R.; Patlewicz, G.Y.; Pease, C.K. Investigation of the skin sensitizing activity of linalool. Contact Derm. 2002, 47, 161-164.

232 Ríos, J.L.; Bas, E.; Recio, M.C. Effects of natural products on contact dermatitis. Curr. Med. Chem. Anti Inflamm. Anti Allergy Agents 2005, 4, 65-80.

233 Olthof, M.R.; Hollman, P.C.; Zock, P.L.; Katan, M.B. Consumption of high doses of chlorogenic acid, present in coffee, or of black tea increases plasma total homocysteine concentrations in humans. Am. J. Clin. Nutr. 2001, 73, 532-538.

234 Muller, T.; Woitalla, D.; Hauptmann, B.; Fowler, B.; Kuhn, W. Decrease of methionine and $S$-adenosylmethionine and increase of homocysteine in treated patients with Parkinson's disease. Neurosci. Lett. 2001, 308, 54-56.

235 Hegarty, V.M.; May, H.M.; Khaw, K.T. Tea drinking and bone mineral density in older women. Am. J. Clin. Nutr. 2000, 71, 1003-1425.

236 Estruch, R.; Sacanella, E.; Mota, F.; Chiva-Blanch, G.; Antúnez, E.; Casals, E.; Deulofeu, R.; Rotilio, D.; Andres-Lacueva, C.; Lamuela-Raventos, R.M.; et al. Moderate consumption of red wine, but not gin, decreases erythrocyte superoxide dismutase activity: A randomised crossover trial. Nutr. Metab. Cardiovasc. Dis. 2011, 21, 46-53.

237 Ward, N.C.; Hodgson, J.M.; Croft, K.D.; Burke, V.; Beilin, L.J.; Puddey, I.B. The combination of vitamin $\mathrm{C}$ and grape-seed polyphenols increases blood pressure: A randomized, double-blind, placebo-controlled trial. J. Hypertens. 2005, 23, 427-434.

(C) 2013 by the authors; licensee MDPI, Basel, Switzerland. This article is an open access article distributed under the terms and conditions of the Creative Commons Attribution license (http://creativecommons.org/licenses/by/3.0/). 